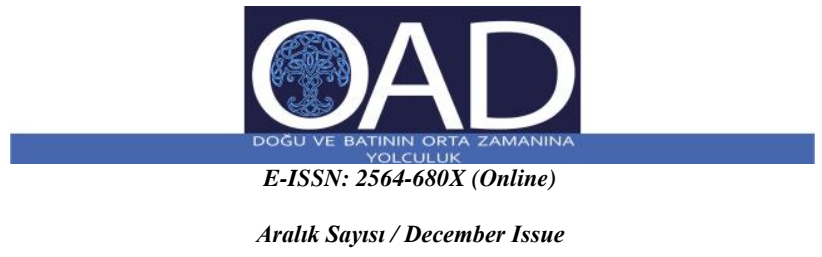

Yıl 3, Sayı 2 / Year 3, Issue 2

ATIF BILGISI / REFERENCE INFORMATION

BAĞCI, Büşra, “Osmanlı Devleti’nin Kuruluş Döneminde Kalenderî Gruplar”, Ortaçă̆ Araştırmaları Dergisi, III/II, Aralık 2020, s. $240-252$.

Makale Türü: Tarih Araştırma

DOI No: https://doi.org/10.48120/oad.804035

Geliș Tarihi / Received: 06 Ekim 2020 Online Yayın: 26 Aralık 2020
Kabul Tarihi / Accepted: 22 Aralık 2020

Published Online: 26 December 2020

\title{
Osmanlı Devleti'nin Kuruluş Döneminde Kalenderî Gruplar
} Büşra BAĞCI ${ }^{*+}$

\author{
${ }^{1}$ Doktora Öğrencisi, Necmettin Erbakan Üniversitesi Sosyal Bilimler Enstitüsü, Tarih Anabilim Dal, KONYA. \\ *bagcibusr@gmail.com \\ +ORCID: 0000-0002-1480-6334
}

Öz- Osmanlı Devleti'nin kuruluş sürecinde birçok tasavvufi fikir hareketleri etkili olmuştur. Cemâleddîn-i Sâvî tarafindan usul ve erkânı belirlenen, onun ve halifeleri tarafından müstakil bir tarikat şekline dönüştürülen Kalenderî zümreler de kuruluş sürecinde büyük rol oynamıştır. Kalenderîlik, Orta Asya ve İran'da ortaya çıkmış, XIII. yüzyılda Moğol istilası sonucunda Anadolu topraklarında yayılma imkânı bulmuştur. Moğol istilası sebebiyle Selçukluların bölgedeki hakimiyetinin zayıflamasıyla birlikte, heterodoks gruplar İlhanlı tahakkümünün de etkisiyle Anadolu'daki varlıklarını daha da arttırmışlardır.

Osmanlı Devleti’nin kuruluşuna kadar Anadolu'daki Kalenderîler hakkında bilgi verilerek başladığımız bu çalışmada, Osmanlı Devleti'nin kuruluş döneminde yaşamış, Kalenderî zümrelerin faaliyetleri anlatılmıştır. Kuruluş döneminde yaşamış; Abdal Murad, Doğlu Baba, Postinpûş Baba, Seyyid Ali Sultan (Kızıl Deli), Şücâüddin Veli, Otman Baba ve Koyun Baba'nın yaşamlarına dair genel bir değerlendirmeden sonra kuruluş döneminde halk üzerindeki nüfuzları, devletin kuruluş sürecine etkileri Osmanlı beylerinin gaza ve fetih mücadelelerindeki rolleri ele alınmıştır. Kalenderî zümrelerin Osmanlı kronikleri ve her bir dervişe ait olan menâkıbnâmeler ışı̆̆ında Osmanlı devletinin kuruluşuna etkileri, Osmanlı sultanları ile ilişkileri, hanedan ailesi ile yakınlıkları ve halk üzerindeki nüfuzuna değinilmiştir. Ayrıca bu Kalenderî zümrelerin, Osmanlı sultanları ile ilişkileri, politikaları, siyasetlerindeki değişim dönem dönem ele alınmıştır.

Anahtar Kelimeler-Kalenderî, Osmanlı Devleti, fetih, heterodoks.

\section{Kalenderî Groups During the Foundation Period of The Ottoman State}

Abstract- Many sufi ideas had been effective in the establishment process of the Ottoman State. The Kalenderî groups, which their methods and principles were determined by Cemâleddîn-i Sâvî and turned into a detached cult by him and his caliphs also played a major role during the establishment process. Kalenderilik emerged in Central Asia and Iran and caught the opportunity of spreading on Anatolian land as a result of the Mogol invasion in the XIII. century. With the fact that the Seljuk's dominance wakened due to the Mongol invasion, heterodox groups have increased their presence in Anatolia also with the influence of Ilkhan domination.

In this study, which we started by giving information about the Kalenderîs in Anatolia, the activities of the Kalenderî groups that lived during the foundation period of the Ottoman State were explained. After a general consideration about the lives of Abdal Murad, Doğlu Baba, Postinpûş Baba, Seyyid Ali Sultan (Kızıl Deli), Şücâüddin Veli, Otman Baba and Koyun Baba lived in the foundation period , their authority on the people during the establishment period, their influence on the establishment process of the state, their role in the gaza and conquest struggles of the Ottoman gentlemen were discussed. In light of the Ottoman chronicles of the Kalenderî groups and menakıbnames belonging to each other dervishes, their influence on the establishment of the Ottoman Empire, their relations with the Ottoman sultans, their closeness with the dynast family and their authority on the people were mentioned. In addition, the relations, policies and changes in politics of these Kalenderî groups with the Ottoman sultans were discussed period by period.

Keywords - Kalenderî, Ottoman State, conquest, heterodox 


\section{Giriș}

Selçukluların Anadolu'yu fethe başlamasıyla beraber, Anadolu topraklarına birçok derviş, fakih ve mutasavvıf göç etmeye başlamış, XIII. yüzyılda yoğunlaşan göçler, Moğol istilasının başlamasıyla zirveye ulaşmıştır. Bu göçler neticesinde Anadolu'da Bektaşîlik, Mevlevîlik, Rufaîlik, Kâzerûnîlik, Kadirîlik, Halvetîlik, Haydarîlik ve Kalenderîlik gibi tarikatlar ortaya çıkmış ve zamanla hızlı bir şekilde geniş zümrelere yayılmıştır. $\mathrm{Bu}$ tasavvufi zümreler teşkilatlanarak Anadolu'nun fethinde önemli roller oynadıkları gibi İslamlaşmasında ve Türkleşmesinde en büyük paya sahip olmuşlardır. Halk arasında menkıbe ve kerametleriyle tanınan dervişler, daha çok İslamiyet'in mistik yönünü ön plana çıkaran bir öğretiyi temsil etmişlerdir. $\mathrm{Bu}$ tasavvufi zümreler içerisinde Anadolu'nun Moğol tahakkümüne girmesiyle beraber en güçlü hale gelenler Kalenderî gruplar olmuştur. ${ }^{1}$ Kalenderî zümreler genellikle tufeyli bir yaşam sürdürmelerine rağmen bazı Kalenderîler, yerleştikleri bölgede vergiden muaf ve halktan biri gibi tarım ve hayvancılıkla uğraşmışlardır

Anadolu'da İlhanlı hâkimiyetinin zayıflamasıyla beraber bağımsızlığını ilan eden beylerden biri de Osman Bey olmustur. Uç bölgede bulunan Kayıların gaza faaliyetlerine birçok Türkmen iştirak ettiği gibi yanlarında çok sayıda mutasavvıf, derviș, abdal, baba ve alperen de bölgeye gelerek gazalara katılmıştır. Osmanlı Devleti'nin kuruluş döneminde Anadolu'da birçok zümrenin aktif olarak yer aldığını bildiren Aşıkpaşazâde, Osmanlı Devleti'nin kuruluş sürecinde dört zümrenin varlığından ve etkisinden bahsetmektedir. Bunlar; Abdalan-1 Rum, Ahiyan-1 Rum, Gaziyan-1 Rum ve Bacıyan1 Rum'dur. Bu dört zümre içerisinde, o dönemde halk arasında daha çok abdal, derviş, dede, baba ve eren olarak isimlendirilen Rum abdalları ön planda yer almıştır. Osmanlı Devleti'nde yer alan Kalenderî gruplarda (Cavlâki, Haydarî, Rıfaî) bu abdallardan oluşan zümrelerden biridir. Kalenderîlerin, Osmanlı Devleti'nin kuruluşundan kâmil devlet olduğu Fâtih devrine kadar Osmanlı toplumunda aktif olarak bulundukları söylenebilir. Kalenderîler, Fâtih'e kadarki dönemde, hükümdar ve devlet adamları ile iyi ilişkiler içerisinde olmuşlar, pek çok sefere de iştirak etmişlerdir.

\section{A. Kalenderîlik ve Osmanlı'ya Kadar Anadolu'da Kalenderîler}

Dünyayı ve dünyevi değerleri umursamayan, içinde yaşadıkları topluma ve bu toplum düzeninin inanç ve geleneklerine karşı çıkan, bunu da kılık kıyafet tutum ve davranıșlarıyla gündelik hayatlarına yansitan sûfilere Kalender denmektedir. Bunların temsil ettiği tasavvufi zümrelere de genel olarak Kalenderîyye veya Kalenderîlik adı verilmektedir. ${ }^{2}$ Kalenderîliğin, X. yüzyıldan itibaren Horasan'da ortaya çıkıp Kalender niteliği taşıdığı öne sürülen Baba Tâhir-i Uryân, Baba Hemşa gibi bazı sûfiler ve onların çevreleriyle sınırlı bir tasavvuf akımı ve sosyal bir muhalefet unsuru olarak ortaya çıktığ söylenmektedir. ${ }^{3}$

Kalenderîler, muhtemelen Melamilikte vurgulanan toplum tarafindan dışlanma felsefesinin bir yansıması olarak ortaya çıkmış olan "görünüş ve yaşayış" farklılıklarına sahip şahsiyetlerdir. Kalenderîler, tuhaf görünüşleri ile toplumda tiksinti yaratmak ve bu şekilde toplumdan dışlanmayı sağlamayı amaçlamışlardır. Bu amaca

${ }^{1}$ Mustafa Akkuş, Moğollarda Din ve Siyaset, Çizgi Kitabevi, Konya, 2020, s. 128 .

${ }^{2}$ Nihat Azamat, "Kalenderiyye", DİA, C.XXIV, İstanbul, 2001, s.253.

Ahmet Yaşar Ocak, Osmanll Imparatorluğunda Marjinal Sufilik Kalenderîler (XIV-XVII. yüzyıllar), TTK Yayınları, Ankara, 1992, s.16-23.

${ }^{4}$ Hilmi Ziya Ülken, Anadolu'nun Dinî Sosyal Tarihi (Öncüler Barak Baba, Geyikli Baba, Hacı Bektaş), Çeviren ve Yayına Hazırlayan: Ahmet Taşğın, Kalan Yayınları, s.75 vd.

${ }^{5}$ Ocak, Osmanlı Imparatorluğunda Marjinal Sufilik, s.158-165;Fuat Köprülü, Türk Tarih-i Dinîsi, Haz: Metin Ergun, Akçağ Yayınları, Ankara, 2005, s.150, Ahmet T. Karamustafa, Tanrının Kuraltanımaz Kulları, Çev. Ruşen Sezer, Yapı Kredi Yayınları, İstanbul, 2008, s.27-33.

${ }^{6}$ Mustafa Akkus, "Anadolu Selçuklu Devletinin Yıkılmasında Kalenderi Grupların Rolü”, Turkish Studies, Volume 9/7 Summer 2014, Ankara, s.121. uygun olarak da çıplak veya yarı çılak dolașmıșlardır. ${ }^{4}$ Bazıları kıldan dokunmuş ve cavlak adı verilen yün çuvallar giymişlerdir. Bu nedenle Kalenderîlere "cavlakiyye" adı da verilmiştir. Kalenderîler saç, sakal, bıyık ve kaşların ustura ile kazındığı "çehâr darb (Çârdarb)" denilen bir anlayışı benimsemişlerdir. Üzerlerinde dilenci çanağ1 ve derviş değneği yanında balta, deri torba, büyük tahta kaşıklar ve aşık kemikleri taşımışlardır. Bütün bu özelliklerinden dolay1, Kalenderî dervişlerine karşı toplumun her kesiminden, özellikle ulemadan büyük bir tepki gösterilmiştir. Ulema, onları şeriatın dışına çıkmakla itham etmiştir. $\mathrm{Bu}$ ve benzeri ithamlar sebebiyledir ki Kalenderîler, “zındıklık ve mülhidlik”le suçlanmışlardır. ${ }^{5}$ Tarih kaynakları; Kalenderîleri, helal veya mubah gibi kavramları dikkate almayan, harama riayet etmeyen, namaz kılmayıp açıktan olmasa bile gizlice oruç yiyen ve şarap içen, hiçbir küfürden çekinmeyip dilencilikle geçinen ve iș ve meslek kaçkını tembeller olarak görüp, halkın sırtında geçinen kişiler olarak tasvir etmektedir. ${ }^{6}$

Kalendirîliğin, ilk olarak Orta Asya ve İran'da ortaya çıktığı rivayet edilmektedir. XII. ve XIII. yüzyıllarda Orta Doğu'da, Moğol istilası sonucu yaşanan siyasî ve içtimaî olayların etkisiyle tarikat teşkilatlanarak hızla yayılmıştır. İlk teşkilatlanmayı gerçekleştiren şahsın Cemâleddin Sâvî olduğu iddia edilmektedir. Savi, İran'ın Sâve şehrinde doğmuş, Mısır'ın Dimyat şehrinde vefat etmiştir. ${ }^{7}$ Şeyh Osman-1 Rûmî adında, Sünnî bir şeyhe intisap eden Cemâleddin Sâvî, tasavvuf yoluna girmiștir. Moğol istilası sırasında Şam'a gelerek, Celâl-i Dergezînî adında yarı çıplak dolaşan birisiyle dostluk kurmuş, açtığ1 zâviyede onun gibi yaşamaya başlamıştır. ${ }^{8} \mathrm{Bu}$ yaşantısı sebebiyle halktan tepki görünce Dimyat'a gitmek zorunda kalmıştır. Kendisine mürid olan bir kadının yaptırdı ̆̆ı zâviyede altı yıl yaşadıktan sonra 1232/1233 yılında burada vefat etmiştir. ${ }^{9}$

Cemâleddin Sâvî'nin ölümünden sonra kendisinin halifelerinden birisi olan Ebû Bekr-i Niksârî 1206 yılında Konya'ya gidip, burada bir zâviye kurarak müridleriyle birlikte meşrebini yaymaya başlamıştır. ${ }^{10}$ Ebû Bekr-i Niksârî ve müridleri, Eflâkî tarafından Cavlâkî diye nitelendirilmektedir. Eflâkî, Konya'daki bu Kalenderan grubu hakkında ayrıntılı bilgi verirken bir de Ebû Bekr-i Niksârî’nin yakını olan Şeyh Ömer-i Girîhî adında bir başka Kalenderî şeyhinden bahsetmektedir. ${ }^{11}$ Ebû Bekr-i Niksârî, Konya'da, Mevlânâ ve Mevlevîlerden büyük destek ve yardım görmüştür. ${ }^{12}$

Kalenderîlerin Anadolu'ya ilk geldikleri tarih tam olarak bilinmemekle birlikte XIII. yüzyılın ilk çeyreğinden itibaren bölgede varlıklarını hissettirmeye başlamışlardır. Yesevîlik, Haydarîlik, Vefâilik gibi tarikatlar aracılığıyla Anadolu'ya giren Kalenderîlik, bu coğrafyada çok etkili olmuştur. Kalenderîler Anadolu'ya geldikleri zaman, Moğollar, Selçuklu Devleti'nde etkin bir konumda yer almaktaydılar. Selçukluların zayıflamasını firsat bilen Moğollar, bu dönemde Anadolu'da istedikleri şahsı sultan yapıp iktidara getiriyorlar, bazı devlet adamlarını da amaçları doğrultusunda kullanıyor ve atadıkları komutanlar vasıtasıyla ülkeyi istedikleri gibi yönetiyorlard $1 .{ }^{13}$ Anadolu'da Osmanlı öncesi dönemde, Aybek Baba ve Barak Baba adlı iki Türk şeyhi Kalenderîlikte aktif bir konumda bulunmuștur. $\mathrm{Bu}$ șeyhler Anadolu Selçuklu Devleti'nin son dönemlerinde Moğollar ile ittifak kurarak, Selçuklular aleyhinde

${ }^{7}$ Ahmet Yaşar Ocak, Osmanlı Toplumunda Zındıklar ve Mülhidler (15-17 Yüzylllar), Tarih Vakfi Yurt Yayınları, İstanbul, 2013, s.134.

${ }^{8}$ Sadullah Gülten, "Tahrir Defterlerine Göre Anadolu'da Kalenderîler ve Haydarîler”, Tarih Araştırmaları Dergisi, C.XXXI, S.52, 2012, s.37.

${ }^{9}$ Tahsin Yazıcı, "Cemâleddin-i Sâvî", DİA, C.VII, İstanbul, 1993, s.314.

${ }^{10}$ Ocak, Osmanlı Imparatorluğunda Marjinal Sufilik, s.27; Akkuş, "Anadolu Selçuklu Devletinin Yıkılmasında", s.120-121.

${ }^{11}$ Ahmed Eflâkî, Âriflerin Menkıbeleri, Cev: Tahsin Yazıcı, C.II, Hürriyet Yayınları, İstanbul, 1973, s.63; Akkuş, "Anadolu Selçuklu Devletinin Y1kılmasında", s.121.

${ }^{12}$ Eflâkî, II, s.63; Ocak, Osmanlı Imparatorluğunda Marjinal Sufilik, s.63.

${ }^{13}$ Mustafa Akkuş, Büşra Bağcı, "Hülâgû Han Döneminde Anadolu'da Görev

Yapan Moğol Komutanları”, USAD, Güz 2018, S.9, s.153. 
hareket etmişlerdir. Hayatı hakkında yeterli bilgi bulunmayan Aybek Baba, Babaî çevreleriyle ilişkisi içerisinde olup, 1256 yılından sonra Moğollarla işbirliğinin faydalı olacağına inanan bir kişi olarak bilinmektedir. ${ }^{14}$ Aybek Baba, Anadolu'da yaşadığı dönemde ünlü Selçuklu Veziri Muîneddîn Pervâne (öl. 1277) ile anlaşamamış, Pervâne tarafindan bir takım suçlamalara maruz kalmıştır. Tarihi kaynaklar, Aybek Baba hakkındaki bu suçlamaların sebebi olarak, onun Amasya'da Mevlevîleri desteklemesi ve kendisinin Baba İshak gibi hareket etmesini göstermişlerdir. Yaşanan bu olaylar neticesinde, Aybek Baba tekkesini bırakarak, 1271 yılında Mısır'a kaçmıştır. ${ }^{15}$

Aybek Baba, Mısır'a gittikten sonra "hulûl ve ittihâd'a dair sözler sarf etmiş; bunun üzerine ulemadan oluşan bir heyet tarafindan Memlük Sultanı el-Meliku'z-Zahir Baybars'ın huzurunda muhakeme edilmiş ve cezalandırılmıştır. ${ }^{16}$ Şeyh, yaşadığı bu olayın sebebi olarak Pervâne Muîneddîn'i suçlamıștır. Ayrıca Aybek Baba, Muîneddîn Pervâne'yi Selçuklu Sultanı IV. Rükneddîn Kılıç Arslan'ın (12621266) ölümünden sorumlu tutmuş ve bu vezire karşı kin beslemiştir. Hem Pervâne'den, hem de Mısır sultanından intikam almak isteyen Aybek Baba, çareyi Abaka Han'a sığınmakta bulmuştur. İlticâ ardından Abaka Han'ın güvenini temin eden Aybek Baba, orada ulemanın teveccühünü kazanıp, Moğollar'a hizmet etmiş ve onları İslâm'a davet etmiştir. Bu süreçten sonra Abaka Han'ın câsusu olduğu iddia edilen Aybek Baba, Anadolu'da Pervâne ile Misır Sultanı Baybars arasında Moğollar'a karşı gizli bir ittifak içerisinde olduklarını İlhan'a bildirmiștir. Ayrıca Aybek Baba, Pervâne'nin Baybars ile yaptığı yazışmaları ele geçirerek bu mektupları Abaka'ya vermiștir. ${ }^{17}$ Böylece vezirin sonunu hazırlayarak intikamını almıştır. ${ }^{18}$ Yaşanan bu olayların ardından Aybek Baba'nın, 676/127778 yılında Amasya'daki hankâhına dönerek, burayı tekrar faaliyete geçirdiği tarihi kaynaklarda ifade edilmiştir. ${ }^{19}$

Anadolu'da Moğollar ile işbirliği yapan dervișlerden biri de Barak Baba'dır. Babaî hareketi çevrelerine mensup Kalenderîyye tarikat şeyhlerinden bir Türkmen babası olarak bilinen Barak Baba'nın doğum tarihi ve yaşamı hakkında pek fazla bilgi bulunmamaktadır. Anadolu'da Moğol askerleri ve yönetimi çevresine girmeyi başararak adından çokça söz ettiren Barak Baba'nın şöhreti kısa zamanda İran'daki Moğol-İlhanlı sarayına kadar ulaşmıştır. Dönemin İlhanl hükümdarı Gâzân Han (1295-1304) ve Olcaytu Hudâbende döneminde itibarını korumuş ve onların hizmetinde görev almıştır. ${ }^{20}$ Barak Baba, Olcaytu Han döneminde hac dönüşü Gilan'da bulunan Sultan'ın yanına giderken, Gilanlar tarafindan yakalanmış ve öldürülmüştür. ${ }^{21}$ İlhanlı Sultanı, saygı duyduğu bu şeyhe bir yarlıkla Sultaniye'de yüksekçe türbe yaptırmış ve müridlerine her gün verilmek üzere elli dinar maaş bağlatmıștır. ${ }^{22}$

\section{B. Osmanlı Devleti’nin Kuruluş Döneminde Kalenderî Gruplar}

Moğol istilası ile Anadolu'ya yoğun olarak gelen tasavvufi zümrelerin en etkilisi Kalenderîlerdir. ${ }^{23}$ Anadolu Selçukluları döneminde Anadolu'da büyük bir güç ve nüfuz elde eden Kalenderîlerin Osmanlı devrinde eski güç ve statülerini kaybetseler de, İslam dünyasının çeşitli zaman ve mekânlarında pek çok değişik isim ve lakaplarla varlıklarını sürdürmüşlerdir. Selçuklu devrinde; Kalenderî, Cavlakî ve Haydarî, Beylikler Döneminde ise Anadolu

\footnotetext{
${ }^{14}$ Ocak, Osmanlı Imparatorluğunda Marjinal Sufilik, s.68.

${ }^{15}$ Hüseyin Hüsameddin Efendi, Amasya Tarihi, haz: Mesut Aydın-G. Aydın, C.II, Amasya Belediyesi Kültür Yayınları, Amasya, 2008, s.404-405; Mustafa Uyar, Bir Ortaçağ Anadolu Sûfîsi Hakkında Yeni Bulgular: Aybek Baba Şeyh mi, Emîr mi?, Belleten, C.LXXVIII, S.283, (December 2014), s.883.

16 Mustafa Akkuş, Illhanlıların Anadolu'daki Dini Siyaseti, Selçuk Üniversitesi Sosyal Bilimler Enstitüsü, Yayınlanmamış Doktora Tezi, Konya, 2011, s.297.

17 Akkus, Moğollarda Din ve Siyaset, s.144-145.

${ }^{18}$ Hüseyin Hüsameddin Efendi, Amasya Tarihi,II, s.413.

19 Hüseyin Hüsameddin Efendi, Amasya Tarihi,II, s.416; Ocak, Osmanl Imparatorluğunda Marjinal Sufilik, s.68; Uyar, Bir Ortaçağ Anadolu Sûfîsi, s.883.

${ }^{20}$ Ocak, Osmanlı Imparatorluğunda Marjinal Sufilik, s.69-70; Ahmet Yaşar Ocak, "Barak Baba", DİA, C.V, İstanbul, 1992, s.61. Barak Baba, Olcâytû
}

Abdalları olarak tesmiye edilen Kalenderî zümreleri, XV. yüzyıldan itibaren de Işık ve Torlak gibi yeni kelimelerle nitelendirilmişlerdir. ${ }^{24}$

Osmanlı Devleti'nin kuruluș dönemindeki ilk sultanlar yaşadıkları dönemin şartlarına göre Kalenderîler ile iyi ilișkiler içerisinde olmuşlar ve adı geçen gruplara imtiyazlar tanımışlardır. Bu dönemde Kalenderî dervişler; Osman, Orhan ve I. Murat gibi ilk bey ve sultanların maiyetinde fetih hareketine katılmışlardır. Osmanlı padișahları onların bu hizmetlerine karşılık zâviye açmalarına izin vermiş ve bu grupları zengin vakıflarla destekleyip güçlendirmişlerdir. ${ }^{25}$ Osmanlı sultanları, bu siyasetleri ile her zaman itikadî düşünceleri ve fiziki şekilleri itibarıyla sosyal ve dini bir rahatsızlık unsuru olmaya elverişli bu zümreleri fetihlere yönlendirerek hazır güç olarak kullanmak ve onları yönetimin yanında tutarak kontrol altında bulundurmak istemişlerdir. Zira Osmanlı yöneticileri, Anadolu Selçuklular döneminde Babaî isyanları ile Aybek Baba ve Barak Baba olaylarında olduğu gibi bu şeyh ve dervişlerin dönemin müstevlileri Moğollarla birlikte hareket edip, Anadolu Selçuklu Devleti'nin başına ne derece büyük gaileler açabileceklerini hesap etmiş olmalıdırlar. Bu nedenle Osmanlı beyleri bu şeyhleri tamamen kendi hallerine bırakmamışlardır. Her birinin faaliyetlerini yakından takip etmişler ve bu hususta titizlik göstermişlerdir.

Osmanlı Devleti'nin kuruluş döneminde birçok tasavvufi zümre etkin bir șekilde faaliyet göstermiștir. Moğol istilası ile birlikte Anadolu'da pek çok heterodoks grup ortaya çıkmaya başlamıştır. Anadolu coğrafyası heterodoks zümreler bakımından oldukça zengin bir bölgedir. Heterodoks zümre içerisinde önemli bir grup da Kalenderîlerdir. Dönemin kaynaklarındaki tasvirlerden ve konuyla ilgilenen araştırmacıların eserlerinden Kalenderî dervişlerden olduğunu düşündüğümüz Abdal Murad, Doğlu Baba, Postinpûş Baba, Seyyid Ali Sultan (Kızıl Deli), Şûcâeddin Veli, Otman Baba ve Koyun Baba gibi marjinal sûfîler Osmanlı sultanlarının maiyetinde fetih hareketlerine katılmışlardır. Osmanlı sultanları da bu dervişler için gerekli yardım ve desteği sağlamışlar, onlar için tekke, zâviye ve yerleşim yerleri ihdas etmişlerdir. Ancak devletin siyasî ve dinî politikasına aykırı faaliyette bulunanlar devlet arazisinin dıșarısına çıkarılmıştır. Nitekim bu durum İbn-i Kemal'in Tevarih-i Alî Osman adlı eserinde de açıkça beyan edilmiştir. Esere göre, Orhan Bey döneminde zaman zaman Kalenderîlerin teftiş edildiği, herhangi bir karışıklık veya ehl-i sünnet dışı inanç ve tavırları halk arasında yayma gibi bir durum tespit edildiği zaman derhal beylik arazisinin dıșına çıkarıldıklarına dair bazı kayıtlara rastlanmaktadır. ${ }^{26} \mathrm{~K}$ ısacas Osmanlı Devleti'nin kuruluş döneminde; Osman, Orhan, I. Murat, Yıldırım Bayezid ve II. Murat döneminde yönetim çevrelerinin Kalenderîlere karșı tavrı, bir yandan bazı imtiyazlarla onları devlet yanında ve yararına kullanmak, bir yandan da mevcut toplumsal düzeni bozmalarına engel olmak şeklinde özetlenebilir.

Fâtih dönemine gelindiğinde Osmanlı Devleti'nin Kalenderîlere karșı tavır ve tutumu aynı şekilde devam etmiştir. İstanbul kuşatması başladığı zaman, diğer tarikat mensupları arasında Kalenderî zümrelerinin de tıpkı ilk dönemlerdeki gibi, ülkenin dört bir yanından kuşatmaya katılmak üzere buraya geldiklerini Oruç Bey

Hudâbende döneminde birçok diplomatik görevlerde ifa etmiştir. O, 1307 yılında yine bir elçilik heyetinin başında gittiği Gilân'da, kendisine "Tatar Şeyhi” diyen Gilanlıların hükümdarı tarafından dervişleriyle birlikte öldürülmüstür. Akkus, a.g.t., s.204.

${ }^{21}$ Cemalü'd-din Ebu'l Kasım Abdullah b. Muhammed b. Ebi Tahir Kâşânî, Tarih-i Olcâytû, Tercüme: Derya Örs, Ankara Üniversitesi Sosyal Bilimler Enstitüsü, Yayınlanmamış Yüksek Lisans Tezi, Ankara, 1992, s.70; Akkuş, Moğollarda Din ve Siyaset, s.233.

${ }^{22}$ Kâsânî, a.g.e., s.70.

${ }^{23}$ Ocak, Osmanlı Imparatorluğunda Marjinal Sufilik, s.61.

${ }^{24}$ Ocak, Osmanlı Imparatorluğunda Marjinal Sufilik, s.93.

${ }^{25}$ Gülten, "Tahrir Defterlerine Göre Anadolu'da Kalenderîler ve Haydarîler", s.38-39

${ }^{26}$ İbn Kemal, Tevârih-i Âli Osman, II. Defter, Yayına Hazırlayan: Şerafettin Turan, TTK,2. Bask1, Ankara, 1991, s.90. 
nakletmektedir. ${ }^{27}$ Fetihten hemen sonra İstanbul'daki bir manastır, bizzat Fâtih tarafindan zâviye olarak Kalenderîlere tahsis edilmiştir. ${ }^{28}$ Fâtih Sultan Mehmet'in Kalenderîlere bir zâviye tahsis etmesi, onları belli bir yerde kontrol altında tutma anlayışından kaynaklanmaktadır. Osmanlı Devleti'nin kuruluşundan itibaren Kalenderî zümrelere karşı yaklaşımları, zaman geçtikçe farklılık arz etmektedir. Devlet'in bu gruplarla ilişkisi kuruluşundan XV. yüzyıl sonlarıyla XVI. yüzyılın başlarına kadar müsbet ve karşılıklı yarar esaslarına dayanırken, bu tarihten itibaren değişen siyasî şartların gereğine göre değişkenlik gösteren bir politika şeklinde devam etmiştir. Türkmen babaların nüfuzu, medreselerin gelişip, merkezi idarenin kuvvetlenmesi ile birlikte yerini ulemaya terk etmiştir.

\section{Abdal Murad}

Osmanlı Devleti kuruluş sürecinde gaza amacıyla birçok bölgeyi fethetmiştir. Osmanlı sultanları seferlere giderken emrindeki askerî kuvvetlerin yanı sıra o dönemde bölgede bulunan gazi ve dervişlerden yararlanmışlardır. Dervişlerde maiyetindeki birçok kişi ile seferlere katılıp, ön saflarda mücadele etmişlerdir. Bu dervişlerden biri de Orhan Gazi döneminde yaşadı $\breve{~} 1$ bilinen ${ }^{29}$ Abdal Murad'dır. Abdal Murad aslen Buharalı olup, Bursa'nın fethinden önce yanında oğlu Abdal Mehmed olduğu halde Anadolu'ya geldiği kaynaklarda anlatılmaktadır. Osmanlı kroniklerinde Abdal Murad'ın güçlü bir cezbe sahibi olduğu ve birçok kerametlerinin bulunduğu belirtilmektedir. Gelibolulu Mustafa Âli Efendi, Orhan Bey döneminde yaşamış meşayihi anlatırken Abdal Murad'1 anlattığ bölümde cümleye bu dervişin meczup olduğundan ve birçok kerametinin zuhur ettiğinden bahsederek başlamıştır. Mecdî ise Osmanlı dönemindeki önemli şahsiyetlere yer verdiği eserinde Abdal Murad'a ait bilgilerin geçtiği kısımda başlığını “ Meczub Rabbani Abdal Murad Rahmetullahi aleyh" şeklinde vermiştir. ${ }^{30}$ Âşıkpaşaoğlu Ahmed Âşıkî, Abdal Murad'1, I. Murad dönemindeki ulemâ ve fukarâ arasında zikredip, Onu açık kerametleri olan ve duaları makbul bir kişi olarak tasvir etmektedir. ${ }^{31} \mathrm{Bu}$ bilgilere ilaveten Köprülü, Abdal Musa gibi onun da Anadolu'ya gelen kırk derviş arasında sayıldığını yazmaktadır. ${ }^{32}$

Bursa'nın fethinden önce Bursa civarına yerleştiği bilinen Abdal Murad daha bu dönemde o bölgede bulunan halkı yıldırmak amacıyla bazı faaliyetlerde bulunmuştur. Taşköprülüzâde ve Mecdî gibi Osmanlı dönemi tarihçileri, Abdal Murad'dan bahsederken onun tepelerden Bursa kalesinin bulunduğu yere taşlar yuvarlamak suretiyle yerel halkı bertaraf etmeye çalıştığını anlatmışlardır. O, bu tür faaliyetlerle fetih öncesi dönemde bölge halkının hayatında büyük bir korku oluşturmuştur. Orhan Bey, Bursa'yı kuşattığında ordudaki yerini alarak düşmana karşı ön saflarda savaşmıştır. ${ }^{33}$ Fetih sırasında, birçok dervişte görüldüğü gibi Abdal Murad'ın da bazı olağanüstü tavırlar sergilediği rivayet edilmektedir. Örneğin, Geyikli Baba'nın kılıca benzer büyüklükteki tahta sopasıyla olağanüstü kahramanlıklar gösterdiği rivayet edilmiştir. Abdal Murad'ın, meşhur tahta kılıcıyla düşmanlara korku salmak için savaş esnasında büyük bir kayayı

${ }^{27}$ Oruç Bey, Tevârih-i Âli Osman, çev: Nihal Atsız, Kervan Kitapçılık, İstanbul, 1972, s. 65

28 Selahattin Döğüș, Osmanlı Devleti'nin Doğuşunda Sosyal Kuruluşlar, Erciyes Ün. Sosyal Bilimler Enstitüsü, Kayseri, 1999, s.133.

${ }^{29}$ Evliya Çelebi, Günümüz Türkçesi ile Evliya Çelebi Seyehatnamesi: Bursa, Bolu, Trabzon, Erzurum, Azerbaycan, Kafkasya, Kırım, Girit, Hazırlayanlar: Yücel Dağlı, Seyyid Ali Kahraman, 2. Cilt, 1. Kitap, 2. Baskı, Yapı Kredi Yayınları, İstanbul, 2008, s.46; Mecdî Mehmet Efendi, Şakaik-i Nu'maniye ve Zeyilleri (Hadâiku'ş-Şekâik), C.I, nş. haz. Abdülkadir Özcan, Çağrı Yayınları, İstanbul, 1989, s.34

${ }^{30}$ Aşıkpaşazâde, Osmanoğullarının Tarihi, Haz.: Kemal Yavuz, M.A.Yekta Saraç, İstanbul, 2003, s.297; Gelibolulu Mustafa Âli Efendi, Kitâbü't- Târihi Künhü'l-Ahbâr, Hazırlayanlar: Ahmet Uğur, Ahmet Gül, Mustafa Çuhadar, İbrahim Hakkı Çuhadar, C.I, Birinci Kısım, Kayseri, 1997, s.107; Mecdî, Sakaik-i Nu'maniye, s.34.

${ }^{31}$ Âşıkpaşaoğlu Ahmed Âşıkî, Tevârîh-i Âl-i Osman, Düzenleyen: Nihal Atsız,

Türkiye Yayınevi, İstanbul, 1947, s.235.

${ }^{32}$ Orhan F. Köprülü, “Abdal Murad”, DIA, C.I, İstanbul, 1988, s.63. ortadan ikiye böldüğü, pek çok düşmanı da bertaraf ettiği anlatılmıştır. Meşhur kerametleri ile bilinen Abdal Murad'ın, Abdal Musa'nın yardımıyla ve Orhan Gazi tarafından komuta etmesi amacıyla kendisine verilen birliğin de desteğiyle fethin başarılı bir şekilde tamamlanmasında büyük hizmetleri olduğu da ifade edilmiştir. $^{34}$

Fetihten sonra Bursa'ya yerleşen Abdal Murad, fetih sırasındaki gayreti münasebetiyle Orhan Gazi'nin vakfettiği Filidar köyünde hayatını devam ettirmiştir. ${ }^{35}$ Osmanlı kroniklerinde Abdal Murad'ın tasavvufun hangi meşrebine bağlı olduğu hakkında net bir bilgi bulunmamaktadır. Ancak Evliya Çelebi Seyhatname adlı eserinde Abdal Murad Sultan tekkesini anlatırken Orhan Bey döneminde inşa edildiğini ve onun bir Bektaşi tekkesi olduğunu söyler. Fakat Abdal Murad'ın Bektaşi olduğuna dair eserinde herhangi bir bilgi vermez. ${ }^{36}$ Araştırma esnasında başvurduğumuz birçok kaynak; Abdal Murad'ın, yaşayış tarzı ve yaşadığı dönem dikkate alındığı zaman Kalenderî zümreler içerisinde yer alabileceğini bize göstermiştir. Abdal unvanını taşıması "Rum Abdalları" adıyla bilinen Kalenderî/Haydarî zümrelere mensup olabileceği tahmininde bulunulmasına sebep olmaktadır. Abdal Murad'ın ölüm tarihi net bir şekilde bilinmemekle beraber Orhan Gazi devrinde öldüğü kayıtlara geçmiştir. Abdal Murad'ın kabri ve kendisine nisbet edilen tekkesi Uludağ'ın yamacında Alişir Irmağı üzerindeki belde kapılarında yer almaktadır. Bursa halkının ziyaret ettiği yerlerden biridir. ${ }^{37} \mathrm{Abdal}$ Murad'ın türbesi içinde üç arşın uzunluğunda bir kılıcı bulunmaktadır. Sultan Ahmed'in bu kılıcın bir arşın kadarını kesip uğur getirsin diye saraya götürdüğü de rivayet edilmektedir. ${ }^{38}$

\section{Doğlu Baba}

Osmanlı'nın kuruluş döneminde Osman Gazi ve Orhan Gazi devirlerinde yaşadığı bilinen, Kalender-meşrep karakteriyle tanınan dervişlerden biri de Doğlu Baba'dır. Efsanevi bir kişiliğe sahip olan Doğlu Baba'nın doğum yeri, doğum tarihi ve ölüm tarihi ile ilgili kesin bilgi bulunmamaktadır. Orhan Bey dönemindeki diğer dervişler gibi Doğlu Baba'nın da Bursa'nın fethi sırasındaki faaliyetleri dolayısıyla tarihi kaynaklarda adı geçmektedir. Nitekim Osmanlı kroniklerinde Sultan ile Bursa'nın fethinde hazır bulunduğu rivayet edilmektedir. ${ }^{39}$

Osmanlı kroniklerinde Doğlu Baba; ermiş, velî ve meczup bir şahsiyet olarak tanımlanmakta ve yardımsever özelliğine dikkat çekilmektedir. Bursa kuşatması sırasında iki taraf arasında çarpışmaların hızlandığı bir dönemde gazilerin ve dervişlerin sıcaktan perişan oldukları ve susuz kaldıkları bir sırada, onlara ayran dağıttı̆̆ 1 da rivayet edilmektedir. ${ }^{40}$ Yaptığ $\mathrm{bu}$ faaliyetle birçok insanın susuzluğunu gidermiş ve onların dualarına mazhar olmuştur. $\mathrm{Bu}$ faaliyetiyle birçok neferin susuzluğunu gidererek onların hayır duasına mazhar olan Doğlu Baba'nın gerçek adı bilinmemekte, Bursa'nın fethi sonrasında bu ismi almış olabileceği tahmin

${ }^{33}$ Gelibolulu Mustafa Âli Efendi, Kitâbü't- Târih-i Künhü'l-Ahbâr I, s.107; Taşköprülüzâde, Osmanlı Bilginleri eş-Şakâiku'n-Nu'mâniyye fî ulemâi'dDevleti'l-Osmâniyye, Çeviren: Muharrem Tan, İz yayıncılık, İstanbul, 2007, s.32; Mecdî, Şakaik-i Nu'maniye, s.34

${ }^{34}$ Evliya Çelebi, Seyehatname 2. Cild 1. Kitap, s.59; Haşim Şahin, Dervişler, Fakihler, Gaziler, Erken Osmanlı Döneminde Dinî Zümreler (1300-1400), 2. Bask1, Yapı Kredi Yayınları, İstanbul, 2020, s.110-111.

35 Haşim Şahin, Osmanlı Devleti'nin Kuruluş Döneminde Dinî Zümreler (1299-1402), Yayınlanmamış Doktora Tezi, Marmara Üniversitesi Türkiyat Araştırmaları Enstitüsü, İstanbul, 2007, s.104.

${ }^{36}$ Evliya Çelebi, Günümüz Türkçesi ile Evliya Çelebi Seyehatnamesi, s.19.

${ }^{37}$ Gelibolulu Mustafa Âli Efendi, Kitâbü't- Târih-i Künhü'l-Ahbâr I, s.107;

Taşköprülüzâde, a.g.e., s.32.

${ }^{38}$ Evliya Çelebi, Seyehatname 2. Cild 1. Kitap, s.59.

${ }^{39}$ Gelibolulu Mustafa Âli Efendi, Kitâbü't- Târih-i Künhü'l-Ahbâr I, s.108;

Mecdî, Şakaik-i Nu'maniye, s.34; Taşköprülüzâde, a.g.e., s.32; Şahin, a.g.t., s.109.

${ }^{40}$ Taşköprülüzâde, a.g.e., s.32; Gelibolulu Mustafa Âli Efendi, Kitâbü'tTârih-i Künhü'l-Ahbâr I, s.108. 
edilmektedir. ${ }^{41}$ "Dûğg" kelimesinin Farsçada "ayran” manasına gelmesi de bahse konu rivayetle birleştirildiğinde Doğlu Baba isminin Bursa'nın fethi sonrası kendisine nispet edildiği görüşünü desteklemektedir. ${ }^{42}$ Gelibolulu Mustafa Âli Efendi'nin, Kitâbü'tTârih-i Künhü'l-Ahbâr adlı eserinde "Doğlu Baba" denilmek, İranî'de "pîşva" manasında olduğu zikredilmektedir. ${ }^{43}$ "Pîşva" kelimesi ise farsça bir topluluğun önderi, lideri anlamına gelmektedir. ${ }^{44}$ Doğlu Baba'nın savaş esnasında yaptığı yardımlar neticesi olarak kendisinin halk tarafından önder olarak görüldüğü söylenebilir. Nitekim Osmanlı kronikleri, Doğlu Baba'yı mühim bir şahsiyet olarak ele almakta, halkın sevip saydığı, değer verdiği bir kişilik olarak aktarmaktadır.

Doğlu Baba'nın Bursa'nın fethinden sonra, Uludağ'ın doğusunda yer alan ücra bir bölgeye giderek geri kalan ömrünü müritleriyle birlikte geçirdiği tahmin edilmektedir. Orhan Gazi döneminde bu bölgede vefat ettiği rivayet edilen Doğlu Baba'nın, Uludağ'ın yüksek bir mevkiinde Karbelen Tepesi denilen bir mahalde tekkesi bulunmaktadır. ${ }^{45}$ Taşköprülüzâde'ye göre Bursa yakınlarındaki bir dağın tepesinde Gökpınarı adlı yer ona nispet edilen mekân olarak bilinmektedir. ${ }^{46}$

\section{Postinpûş Baba (Mehmed Hammârî)}

Asıl adı Mehmed Hammârî olan Postinpûş Baba, Orhan Gazi döneminde Acem diyarından Bursa'ya gelmiş ve I. Murad döneminde yaşamıș bir derviștir. ${ }^{47}$ "Postinpûş" isminin, Kalenderî dervișleri gibi hayvan postu giymesinden, "postin-pûş"48 yani post, kürk giyen manasından verildiği düşünülmektedir. İsminde "baba" kelimesi bulunması ve Kalenderî bir hayat yaşamasından dolayı Ahmet Yaşar Ocak bu dervişinde Kalenderî olabileceğini iddia etmektedir. ${ }^{49}$

Postinpûş Baba bir süre Bursa'da yaşadıktan sonra Yenişehir'e yerleşmiş ve hayatının geri kalan kısmını burada geçirmiştir. Mehmet Neşri'nin Kitabı Cihannüma adlı eserine göre I. Murat muhabbet ettiği dervişlere zâviye yaptırırdı. Nitekim Postinpûş Baba'ya da Yenişehir'de bir zâviye ${ }^{50}$ yaptırmıștır. ${ }^{51}$ Müneccimbaşı bu zâviyenin yapımına 767 (1365-1366) yılında başlandığını söylemektedir. ${ }^{52}$ Yaşamını zâviyesine gelen yolcuların hizmeti ve halkın irşadıyla geçiren Postinpûş Baba, I.Murad'ın beyliği döneminde, Yenișehir'de vefat etmiştir. Kabri Yenişehir'deki zâviyenin içerisinde yer almaktadır. ${ }^{33}$ Postinpûş Baba, tarihi kaynaklarda cezbe ve keramet sahibi bir kişi olarak bilinmekte olup, pek çok kimseyi kendisine bağladığı rivayet edilmiștir. ${ }^{54}$ Osmanlı kronikleri onu yakarmaları, duaları kabul olunan bir veli olarak zikretmektedir. ${ }^{55}$ Tevârîh-i Âl-i Osman adlı eserde Postinpûş Baba "Allah'in sevgili kullarından olup kerametleriyle meşhur bir kimse" olarak tanımlanmaktadır. ${ }^{56}$ Hem yaşadığı dönemde hem de daha sonrasında Bursa halkının teveccühünü kazanmıştır. Türbesi önemli bir ziyaret yeri olup halen

${ }^{41}$ Taşköprülüzâde, a.g.e., s.32; Mecdî Mehmet Efendi, Şakaik-i Nu'maniye, s. 34 .

${ }^{42}$ https://www.kamusiturki.com/ Bkz.:Dûğ Erişim tarihi: 25.08.2020.

${ }^{43}$ Gelibolulu Mustafa Âli Efendi, Kitâbü't-Târih-i Künhü'l-Ahbâr I, s.108

${ }^{44}$ Şemseddin Sami, Kâmûs-ı Türkî, T.C. Kültür Bakanlığı Yayıncılık, 1.Baskı,

İstanbul, 2016, s.367.

${ }^{45}$ Sahin, a.g.t., s. 110.

${ }^{46}$ Taşköprülüzâde, a.g.e., s.32

${ }^{47}$ Âşıkpaşaoğlu Ahmed Âșıkî, Tevârîh-i Âl-i Osman, s.235;Taşköprülüzâde, a.g.e., s.40; Hoca Sadettin, Tacü't-Tevarih, Sad.: İsmet Parmaksızoğlu, C.5, Kültür Bakanlığı Yayınları, Ankara, 1992, s.19;Gelibolulu Mustafa Âli Efendi, Kitâbü't- Târih-i Künhü'l-Ahbâr I, s.130; Mecdî, Sakaik-i Nu'maniye, s.45.

${ }^{48}$ Şemseddin Sami, Kâmûs-ı Türkî, s.362.

${ }^{49}$ Ocak, Osmanlı Imparatorluğunda Marjinal Sûfîlik, s.92.

${ }^{50} \mathrm{Bu}$ zaviye hakkında ayrıntılı bilgi edinmek için bakınız; Vedat Turğut, "XVI Yüzyılda Tahrir Defterlerine Göre Hüdavendigar ve Sultanönü Sancaklarında Abdalân-1 Rum”, Uluslararası Sosyal Araştırmalar Dergisi, C.4 S.19, Güz 2011, s.214

51 Âşık Paşazâde, Osmanoğulları'nın Tarihi, s.117;ÂşıkpaşaoğluAhmedÂşıîn, Tevârîh-i Al-i Osman, $\quad$ s.129, 231;Taşköprülüzâde, a.g.e., s.40; Hoca Sadettin, Tacü't-Tevarih, Yalınlaştıran: İsmet Parmaksızoğlu, C.1, Kültür Bakanlığı Yayınları, Ankara, ziyaret edilmekte ve feyz alınmaktadır. ${ }^{57}$ Gelibolulu Âli'nin eserinde Postinpûş Baba'nın Yenişehir'de bir posta sahip olduğu da belirtilmektedir. ${ }^{58}$

\section{Seyyid Ali Sultan (Kızıl Deli)}

Kızıl Deli adıyla bilinen Seyyid Ali Sultan'ın yaşamına dair dönemin kaynaklarında yeterli bilgi bulunmamaktadır. Hayatı hakkında bilgi sahibi olabileceğimiz kaynak kendi ismi ile kaleme alınmış olan velâyetnâmedir. Bu eser derviş hakkında ve o dönem ile ilgili önemli bilgiler içermektedir. ${ }^{59}$ Seyyid Ali Sultan'ın babası Horasan dervişlerinden Hüseyin Ata'dır. ${ }^{60}$ Bunun yanı sıra Bedri Noyan Seyyid Ali Sultan (Kızıldeli) velâyetnâmesindeki bilgilerin 1şı̆̆̆ında, Ahmed Hamdi Zaza Paşa'nın Mısır'da basılmış Arapça kitabında yer alan bazı ifadelerden hareketle onun Horasan erlerinden Seyyid Hüseyin Ata'nın oğlu olduğunu söylemektedir. ${ }^{61}$ Ancak Seyyid Ali Sultan'dan bahseden belgelerde ve velâyetnâme nüshalarında bu konuya dair bilgi bulunmamaktadır. ${ }^{62}$

Eserdeki olaylar dikkate alındığında Seyyid Ali Sultan'ın, Orhan Gazi, I. Murad ve Yıldırım Bayezid devirlerini idrak ettiği tahmin edilmektedir. Seyyid Ali Sultan, Gelibolu ile Bolayır seferlerine dâhil olduktan sonra, I. Murad zamanında Gazi Evrenos'un başında bulunduğu Keşan ve İpsala seferlerinde aktif bir şekilde yer aldığg rivayet edilmektedir. ${ }^{63}$ Ayrıca Seyyid Ali Sultan ile arkadaşları Balkan topraklarındaki Gelibolu, Bolayır, Kavak, Varmacin, Murtad Kalesi, İpsala, Fare, Dimetoka, Edirne, Şumnu, Rusçuk, Silistre ve Bolu topraklarının alınması için yapılan seferlerde hazır bulunduğu ifade edilmektedir. Velâyetnâmedeki bilgilere göre bu seferlerden kendilerine çokça mal kalmıştır. ${ }^{64}$

Seyyid Ali Sultan ve arkadaşı Seyyid Rüstem Gazi maiyyetlerindeki abdallar ile Yıldırım Bayezid zamanındaki (1389-1402) Rumeli fetihlerine katılmışlar, Dimetoka ve havâlisinin zapt edilmesinde bizzat rol oynamışlardır. Peygamber efendimizin soyundan geldiği iddia edilen Seyyid Rüstem ve Seyyid Ali Sultan'in faaliyetleri menâkıbnâmede oldukça dikkat çekici bir tarzda anlatılmıștır. Rivâyete göre Hz. Muhammed (Sav.) bizzat Yıldırım Bayezid'in rüyasına girerek onların kendi soyundan olduğunu, yanlarındaki "Kırk Er" ile yardımına geleceklerini, bu yüzden kendilerine çok itibar göstermesini istemiştir. Bu rüyadan kısa bir süre sonra iki şeyh, beraberindeki Kırk Abdal'la, Sultan'ın yanına gidip hizmet arzında bulunmuşlar, o da büyük bir saygı ile kendilerini kabul etmiş ve onları Rumeli gazâlarına göndermiștir. ${ }^{65}$

Velâyetnâme'ye göre Rumeli fetihleri sırasında Seyyid Ali Sultan'ın birçok kerametlerinin vuku bulduğu anlatılmıştır. Rivayete göre Seyyid Ali Sultan ve maiyetindeki dervişler Rum bölgesine fetih düzenlediği sırada büyük bir sorun ile karşılaşmışlardır. Rumeli

1979, s.130; Mehmed Neşrî, Kitâb-ı Cihan-nümâ Neşrî Tarihi, Hazırlayanlar: Faik Reșit Unat, Mehmed Altay Köymen, C.I, Türk Tarih Kurumu Basımevi, Ankara, 1949, s.309; Mecdî, Şakaik-i Nu'maniye, s.45.

52 Müneccimbaşı Ahmed B. Lütfullah, Camiü'd-Düvel (Osmanlı Tarihi 1299-

1481), Ceviri: Ahmet Ağırakça, İnsan Yayınları, İstanbul, 1995, s.109.

${ }^{53}$ Hoca Sadettin, Tacü't-Tevarih 5, s.19; Mecdî, Şakaik-i Nu'maniye, s.45;

Sahin, a.g.t., s.111.

${ }^{54}$ Mecdî, Şakaik-i Nu'maniye, s.45

${ }^{55}$ Gelibolulu Mustafa Âli Efendi, Kitâbü't- Târih-i Künhü'l-Ahbâr I, s.130;

Taşköprülüzâde, a.g.e., s.40; Mecdî, Sakaik-i Nu'maniye, s.45.

${ }^{56}$ Âş1kpaşaoğlu Ahmed Âşıkî, Tevârîh-i Âl-i Osman, s.235.

${ }^{57}$ Tassköprülüzâde, a.g.e., s.40.

${ }^{58}$ Gelibolulu Mustafa Âli Efendi, Kitâbü't-Târih-i Künhü'l-Ahbâr I, s.130.

${ }^{59}$ Seyyid Ali Sultan (Kızıldeli) ve Velâyetnâmesi, Haz: Rıza Yıldırım, Türk Tarih Kurumu Yayınları, Ankara, 2007, s. 12.

${ }^{60}$ Seyyid Ali Sultan (Kizlldeli Sultan) Velayetnamesi, Haz: Bedri Noyan, Ayyıldız Yayınları, Ankara, 1999, s.3.

${ }^{61}$ Seyyid Ali Sultan (Kuzldeli Sultan) Velayetnamesi, 1999, s.5.

${ }^{62}$ Hașim Şahin, "Seyyid Ali Sultan", DİA, C.XXXVII, İstanbul, 2009, s.49.

${ }^{63}$ Seyyid Ali Sultan (Klzlldeli) ve Velâyetnâmesi, 2007, s.19.

${ }^{64}$ Seyyid Ali Sultan (Klzlldeli) ve Velâyetnâmesi, 2007, s.92.

${ }^{65}$ Ocak, Osmanlı Împaratorluğu'nda Marjinal Sûfílik, s.96-97; Seyyid Ali Sultan (Kuzldeli Sultan) Velayetnamesi, 1999, s.11. 
tarafina gitmek için bulunan geminin reisi, alperenleri karşıya geçirmek istememiş ve gemilerini alıp denizin kenarından ayrılmak suretiyle uzaklaşmıştır. Bu durumu gören Seyyid Ali Sultan keramet göstermiş, bir avuç toprağı denize serpmesinin ardından denizin üstünde topraktan yol oluşturmuş ve bu yolun üzerinden geçmiştir. $\mathrm{Bu}$ olaya şahit olan gemi kaptanı derhal geri dönüp Seyyid Ali Sultan'dan özür dilemiş ve erenleri gemiye almak suretiyle gitmek istedikleri yer olan Gelibolu'ya götürmüştür. Gelibolu'ya vardıklarında Seyyid Ali Sultan'ın bir nidasıyla büyük bir deprem meydana gelmiş, depremden dolayı gayrimüslimlerin çoğu ölmüş, diğerleri de büyük bir korkuya kapılmışlardır. Seyyid Ali Sultan'ın bu kerametine şahit olan gayrimüslimler ona boyun eğmiş ve bazıları İslam dinine geçmiş bazıları da cizye-güzar olmuşlardır. ${ }^{66}$

Seyyid Ali Sultan, Balkan topraklarındaki fetihlerin ardından ordusunu komuta etmesi için Gazi Evrenos'u görevlendirmiş, daha sonra Dimetoka civarında bulunan Kızıldeli isimli toprağın yanındaki nehrin kenarına dergâhını yapmıştır. Dergâh sonraki zamanlarda da çok aktif bir şekilde faaliyetlerine devam etmiş, ayende ve ravendenin de faydalandığ 1 bir yer haline gelmiştir. Ayrıca bu dergâh derbent olarak da kullanılmıştır. ${ }^{67}$ Timur ve ordularının Anadolu'yu tahribatından dolayı Pir-evi kaldırılmış, Seyyid Ali Sultan da Dimetoka'da bir mesken kurmuş ve dergâh yapmıștır. Rivayete göre Seyyid Ali Sultan'ın hayatı bu dergâhta son bulmuştur. ${ }^{68}$

Ahmet Yaşar Ocak, Osmanlı Împaratorluğu'nda Marjinal Sûfílik: Kalenderîler (XIV-XVII. Yüzyıllar), adlı eserinde Seyyid Ali Sultan'ın Rumeli fetihlerinden sonra bu bölgede kendi kılıçlarıyla ele geçirdikleri bir arazide zâviyesini kurarak yerleșmiş olduğunu yazmış ve bu yer ile ilgili net bir bilgi vermemiştir. ${ }^{69}$ Velâyetnâme de geçen bilgiye göre Kızıl Deli Sultan zâviyesinin ${ }^{70}$, tam olarak hangi tarihte kurulduğu bilinmemekle birlikte, I. Bayezid (1389-1403) devrinde Dimetoka' da yer aldığ 1 belirtilmektedir. ${ }^{71}$

Seyyid Ali Sultan'ın bağlı olduğu meşrebi hakkında tarihçiler arasında farklı görüşler ortaya çıkmıştır. Bazı tarihçiler onun Bektaşî çevreleriyle ilişki içerisinde olduğu ve onunda bir Bektaşî olduğunu söylemişlerdir. $\mathrm{Bu}$ duruma kaynak olarak Abdal Musa Velâyetnâmesi'ndeki bazı bilgileri göstermişlerdir. Abdal Musa velâyetnâmesine göre; Seyyid Ali Sultan ve arkadaşları Horasan'dan Anadolu'ya geldikleri zaman ilk olarak Hacı Bektâş Velî dergâhına uğramışlar ve daha sonra Osmanlı topraklarına geçmişlerdir. Ancak Seyyid Ali Sultan ve beraberindeki kişilerin Hacı Bektâş Velî ile görüşmeleri kronolojik olarak mümkün değildir. Ayrıca Abdal Musa Velâyetnâmesi'ndeki bazı ifadelerde Abdal Musa ve Seyyid Ali Sultan'ın Hacı Bektâş Veli ocağında birbirini tanıdıkları, Seyyid Ali Sultan'ın Abdal Musa'nın müridi olduğu ve onun emriyle Gazi Umur Bey ile birlikte Balkan (Boğaz Hisar'ın) fetihlerine katıldığı rivayet edilmektedir. ${ }^{72}$ Tarihçiler tüm bu olayları değerlendirerek onun Bektâşî geleneğine mensup bir derviş olduğunu iddia etmişlerdir.

${ }^{66}$ Seyyid Ali Sultan (Kuzldeli) ve Velâyetnâmesi, 2007, s.16.

${ }^{67}$ Barkan, a.g.m., s.293.

${ }^{68}$ Seyyid Ali Sultan (Kızıldeli) ve Velâyetnâmesi, 2007, s.34.

${ }^{69}$ Ocak, Osmanlı Imparatorluğu'nda Marjinal Sûfilik, s.96.

${ }^{70}$ Ömer Lütfi Barkan bu zâviye hakkında önemli bilgiler vermiştir. Buna göre Kızıl Deli velâyetnâmesinde yer alan Osmanlı arşiv kayıtlarına göre, Rumeli fütuhatında göstermiş olduğu başarılardan dolayı Yıldırım Bayezid tarafından Dimetoka yakınlarındaki "Kara Bükü” (Darı Bükü) adındaki bir köy, Seyyid Ali Sultan'a 804 tarihli bir mülknâme ile vakıf olarak tahsis edilmiştir. O tarihten beri Kızıl Deli oğullarının tasarruflarında olan Tatar Viranı ve Tatarlık gibi mezraalar zâviyelerine inen yolculara hizmet etmek için evlâdlık vakıf olarak kayıtlıdır. Vakfın müessesi ve ataları adına izâfeten "Kızıl Delü Derbendi" ismi verilen bu yer 58 Müslüman ve 23 kâfir haneli bir köy haline gelmiştir. Bkz.: Ömer Lütfi Barkan, "Osmanlı İmparatorluğunda Bir İskân Ve Kolonizasyon Metodu Olarak Vakıflar Ve Temlikler I: İstila Devirlerinin Kolonizatör Türk Dervişleri Ve Zaviyeler," Vakıflar Dergisi, 1942, S.2, s.293; Ali Sinan Bilgili, "Osmanlı arşiv belgelerine göre Kızıldeli (Seyyid Ali Sultan) zâviyesi (1401-1826)" adlı makale çalıșmasında günümüze kadar ulaşmış olan bu zâviyenin, Yunanistan'ın Evros iline bağlı Dimetoka ilçesinin
Nitekim Bektaşîlere ait araştırma çalışmalarında Seyyid Ali Sultan'1 da ele almışlar ve onu da Bektaşî olarak kabul etmişlerdir. ${ }^{73}$

Kalenderîler hakkında müstakil bir kitap yazan Ahmet Yaşar Ocak ise Seyyid Ali Sultan'ın yaşayış tarzı ve velâyetnâmelerdeki bilgilere göre Kalenderî gruplar içerisinde yer aldığını iddia etmiş ve Osmanlı Împaratorluğu'nda Marjinal Sûfilik: Kalenderîler (XIV-XVII. Yüzylllar), adlı eserinde de Seyyid Ali Sultan'1 Kalenderî gruplar içerisinde göstermiştir. ${ }^{74} \mathrm{Biz}$ de gerek dış görünüşü, gerek yaşayış tarzı olarak Kalenderî-Haydarî bir anlayış benimsemesinden dolayı Seyyid Ali Sultan'1 Kalenderî gruplar içerisinde göstermeyi uygun bulduk. Seyyid Ali Sultan ve diğer dervişlerin Bektaşî ya da diğer gruplar içerisinde gösterilmiş olması bu dervişlerin ölümünden sonraki dönemlerde aramak daha uygun olur. Nitekim Osmanlı Sultanlarından II. Beyazıd ${ }^{75}$ ve Kanunî dönemlerinde Kalenderîler çok fazla takip altına alınmış, bazen tekkeleri, zâviyeleri kapatılmış ya da başka bir tarikatın kisvesi altında bu yerlerde faaliyetlerini sürdürmelerine izin verilmiştir. Osmanlı kroniklerinden Nişancı Mehmed Paşa, Kanuni Sultan Süleyman'ın Kalenderî zâviyelerini teftişe tabi tutturduğunu, bunun sonunda pek çok Kalenderînin zâviyelerden sürülüp çıkarıldığını ve muhtelif kalelerde hapsedildiğini rivayet etmektedir. ${ }^{76}$ Neticede Osmanlı Devleti'nin kuruluş sürecinde önemli faaliyetlerde bulunan Kalenderî zümreler Osmanlı Devleti'nin yükselme döneminde geri planda kalmış ve varlıklarını Bektaşî veya diğer tarikatlar aracılığıyla sürdürmek zorunda kalmışlardır.

XV. yüzy1l Kalenderî dervişlerinden biri olan Seyyid Ali Sultan yaşadığ dönemde Rumeli ve Balkanlarda birçok fetih hareketlerinde bulunmuştur. Seyyid Ali Sultan, Balkan topraklarını ele geçirmenin ve o bölgeye yerleşmenin ne kadar önemli olduğunu fark etmiş ve buralara yapılan fetihlerde aktif rol oynamıştır. Balkanları Türkleștirme ve İslamlaştırma faaliyetlerinde önemli katkısı olmuştur. Ancak İslam'a girmek istemeyen kişileri bazen cezalandırmış, bazen de öldürmüştür. ${ }^{77}$ Kendisi adına yazılan velâyetnâmeye göre fetihler sirasında birçok kerametlerde bulunarak fethin kolaylaşmasını sağlamıştır. ${ }^{78}$ Bununla birlikte velâyetnâmede bu sûfilerin kendilerine has savaş tekniklerini de kullandikları ifade edilmiştir. Bunlardan birisi, gayrimüslimlere gözdağı vermek ve ürkütmek adına kâfir bir kişiyi öldürdükten sonra șișe geçirip ateșle yakmalarıdır. ${ }^{79}$

\section{5. Şücâüddin Velî}

Kalenderî gruplar içerisinde yer almış, XV. yüzyılda Anadolu'da etkili olmuş dervişlerinden biri de Şücâüddin Velîdir. Yaşamına dair bilgilerin önemli bir kısmı, XV. yüzyılın ortalarında yazıldığ anlaşılan Velâyetnâme-i Şeyh Şücâeddîn adlı esere dayanmaktadır. Sultan Varlığı, Şücâüddin Baba isimleriyle de bilinen şeyhin adı tarihi kaynaklarda ilk defa Yıldırım Bayezid devrinin sonlarında geçmektedir. Velâyetnâme-i Otman Baba'da, Timur'un Anadolu'ya geldiğinde vezirleriyle birlikte Şücâüddin Velî’yi ziyaret ettiği,

Küçük Derbend (Roussa) isimli köyünde bulunduğunu söylemiștir. Ali Sinan Bilgili, "Osmanlı Arşiv Belgelerine Göre Kızıldeli (Seyyid Ali Sultan) Zâviyesi (1401- 1826)", Türk Kültürü ve Hacı Bektaş Veli Araștırma Dergisi, S.53, Ankara, 2010, s. 90

${ }^{71}$ Seyyid Ali Sultan (Kuzldeli) ve Velâyetnâmesi, 2007, s.3

72 Abdurrahman Güzel, Abdal Musa Velayetnamesi, Türk Tarih Kurumu Yayınları, Ankara, 1999, s.99, 100, 147-148; Şahin, "Seyyid Ali Sultan”, s.49.

73 Rıza Yıldırım, Bektașî-Alevî Geleneğine Göre Seyyid Ali Sultan, Türk Kültürü ve Hacı Bektaş Veli Araştırma Dergisi, S.53, Ankara, 2010, s.59-88; Ayşe Kayapınar, Trakya-Doğu Rodop Bölgesinde Alevi-Bektaşi Zaviyeleri (XV-XVI. Yüzyıllar), Alevilik-Bektaşilik Araştırmaları Dergisi, S.18, 2018, s.3-38.

${ }^{74}$ Ocak, Osmanlı Împaratorluğu'nda Marjinal Sûfilik, s.96-97.

${ }^{75}$ Döğüş, a.g.t., s.133.

${ }^{76}$ Nişancı Mehmed Paşa, Tarîh-i Nişancl, İstanbul, 1290, s.237-238. Ocak,

Osmanl Împaratorluğu'nda Marjinal Sûfîlik, s.128'den naklen.

${ }^{77}$ Şahin, "Seyyid Ali Sultan", s.48.

${ }^{78}$ Seyyid Ali Sultan (Klzıldeli) ve Velâyetnâmesi, 2007, s.19-21.

${ }^{79}$ Seyyid Ali Sultan (Kızldeli) ve Velâyetnâmesi, 2007, s.167. 
kendisine çokça mal bağışlamak istediği anlatılmaktadır. Ancak şeyhin bunu kabul etmediği ve Timur'dan hemen Anadolu'yu terk etmesini istediğine dair bir menkıbe rivayet edilmektedir. ${ }^{80}$

Şücâüddin Velî, Anadolu Kalenderîliği’nin merkezi sayılan Seyyid Gazi zâviyesine çok yakın bir yerde zâviye açarak yerleşmiş ve daha sonra burada teşekkül eden köye adını vermiștir. Söz konusu zaviyenin adı değişerek Arslanbeyli olmuştur. Ahmet Yaşar Ocak, Şeyh Şücâüddin adı ile Edirne'de II. Murad'ın emri üzerine inşa edilmiş başka bir zâviyenin de olduğunu söylemiştir. Ayrıca şeyhin hayatını anlatan, 1450'lerde kaleme alınmış bir de "Velâyetnâme-i Sultan Şücâüddin" adında bir menâkıbnâmesi bulunduğunu da rivayet etmiştir. ${ }^{81}$ Velâyetnâmede; Şücâüddin Velî’nin Abdal Mehmed, Kaygusuz Abdal, Ümmî Kemal, Seyyid Nesîmî, Hacı Bayrâm-1 Velî gibi dönemin diğer sûfîleriyle ve Timurtaşoğlu Ali Bey gibi devlet adamları ile yakın ilişkiler içerisinde olduğu anlatılmaktadır. Ayrıca Baba Mecnûn, Baba Hâkî, Abdal Yâkub gibi derviş ve sûfîlerinde adları geçmektedir. ${ }^{82}$

Şücâüddin Velî, Osmanlı hânedan mensupları ve bazı devlet adamlarıyla da yakın ilişkiler kurmuş bir derviştir. Çelebi Mehmet ve II. Murat dönemlerini idrak etmiş olan Sultan Şücâüddin, Rumeli fetihlerine katılmıştır. Osmanlı Sultanları arasında önemli şahsiyetlerden biri olarak kabul edilen Şücâüddin Velî, Osmanl devlet adamlarından Timurtaş Paşa ve oğlu Ali Bey ile sıkı dostluk kurmustur. ${ }^{83}$ II. Murad'ın annesi Sehzade Hatun, oğlu Alâeddin Çelebi, Laçinoğlu Paşa ve Timurtaşoğlu Ali Bey de onun görüştüğü kişiler arasında yer almaktadır. ${ }^{84}$ Velâyetnâmede "kaşı kirpiği yoluk" bir kişi olarak betimlenen Şücâüddin Velî, Abdalân-1 Rûm zümresinin önde gelen isimleri arasında yer almaktadır. Ancak Kalenderî(Cavlakî) hayat tarzı bazı kesimlerin ve devrindeki bazı şeyhlerin tepkisini çekmiş, hatta menkıbeye göre okla vurulup öldürülmek istenmiștir. ${ }^{85}$

Şeyh Şücâüddin'in yaşadığı dönemde Kalenderî zümreleri ve Abdalân-1 Rûm üzerindeki etkisi Anadolu ile sınırlı kalmamış, Balkanlar'da da yoğun bir biçimde hissedilmiștir. Nitekim Anadolu'nun değişik bölgelerinde ve Balkanlar'da onun adına izâfe edilen çok sayıda tekke ve köy bulunması bunun en belirgin delili olarak gözükmektedir. Hindistan ve İran'dan birtakım Kalenderî zümrelerinin de onun yanına gelerek kendisini ziyaret etmeleri dervişin yaşadığı sınırları aştığını bize göstermektedir. Ölümünden sonra da Sücâüddin Velî’nin Anadolu ve Balkanlar'daki etkisinin devam ettiği belirtilmiștir. Küçük Abdal, Otman Baba'nın dervişleriyle birlikte Şeyh Şücâüddin'in türbesini her yıl ziyaret ettiğini rivayet etmiştir. Günümüz Alevî zümreleri içinde de kendisine büyük saygı duyulmakla birlikte, bir de bu geleneğe bağlı Alevî ocağı bulunduğu söylenmektedir. ${ }^{86}$

\footnotetext{
${ }^{80}$ Haşim Şahin, "Şücâüddin Velî", DİA, C.XXXIX, İstanbul, 2010, s.247.
}

${ }^{81}$ Ocak, Osmanlı Împaratorluğu'nda Marjinal Sûfílik, s.97.

${ }^{82}$ Yağmur Say, Kalenderî, Alevi ve Bektaşi Kültünde Önemli Bir Alp-Eren Gazi: Şucâ'eddîn Velî (Sultan Varlı̆gl) ve Velâyetnâmesi, Sistem Ofset Matbaacılık, 1. Basım, Ankara, 2010, s.37-38; Sahin, "Sücâüddin Velî", s.247.

${ }^{83}$ Orhan F. Köprülü, Velâyet-nâme-i Sultan Şücaüddin, Türkiyat Mecmuast, C.XVII, İstanbul, 1972, s.181-182; Yağmur Say, “Anadolu'nun Türkleşmesi ve İslamlaşmasında Önemli Bir Kült Kimlik: Şücaaddin Veli (Sultan Varlıg1)", Türk Kültürü ve Hacı Bektaş Velî Araştırma Dergisi, Şücaaddin Veli Ocağı Özel Sayısı, S.37, Bahar 2006, s.114.

${ }^{84}$ Ayşe Yıldız, Şücaaddin Baba Velâyetnamesi, Türk Kültürü ve Hacı Bektaş Velî Araştırma Dergisi, Şücaaddin Veli Ocağı Özel Sayısı, S.37, Bahar 2006 , s.62,64.

${ }^{85}$ Şahin, "Şücâüddin Velî", s.247-248

${ }^{86}$ Say, a.g.e., s. 86 .

${ }^{87}$ Say, "Anadolu'nun Türkleşmesi ve İslamlaşmasında", s.117; Şahin, "Şücâüddin Velî", s.247.

${ }^{88}$ Say, "Anadolu'nun Türkleșmesi ve İslamlaşmasında," s.117; Ayșe Yıldız, "Şücaaddin Baba Velâyetnamesi”, Türk Kültürü ve Hacl Bektaş Veli Araștırma Dergisi, Sücaaddin Veli Ocağı Özel Sayısı, S.37, Bahar 2006, s.51.

${ }^{89}$ Köprülü, Velâyet-nâme-i Sultan Şücaüddin, s.183.
Şücâüddin Velî’nin velâyetnâmesinde, șeyhin Çelebi Mehmed ve II. Murad devrindeki faaliyetlerinden, dönemin devlet ricâli ve meşâyihiyle ilişkilerinden söz edilmektedir. Tarihi kaynaklardaki ifadelere göre, Şücâüddin Velî, Eskişehir Seyitgazi'de yaşamını sürdürmüş, müridleriyle birlikte Bursa, Kütahya, Manisa ve Ankara çevresinde dolaşmıştır. ${ }^{87}$ Esere göre Şücâüddin'in velâyet gösterdiği yerler özellikle Seyyid Gazi merkez olmak üzere, buraya yakın yerde bulunan Melik Gazi, Bayındırözü, Nigârînçalan, Atluçalın, Çamağaç, Karkın köyü ve Kırkkavak gibi yerlerdir. ${ }^{88}$ Sultan Şücâüddin, içlerinde nüfuzlu babalarında bulunduğu yaklaşık 200-300 abdallar ile birlikte umumiyetle köyün yakınında yer alan mevkilerde yaşamını sürdürmüştür. Yazları başka bir yere göç eden dervişin, kışları bir mağarada hayatını idame ettirdiği rivayet edilmektedir. $\mathrm{Bu}$ müddet zarfında ise zengin müridlerinden biri tarafından ihtiyaçları karşılanmış olduğu belirtilmektedir. Sultan Şücâüddin'in, Seyyid Gazi'de bir tekke yaptırarak, buraya yerleştiğine dair bilgilerde bulunmaktadır. ${ }^{89}$

Şücâüddin Velî’nin ölümünden sonra tekkesinin bulunduğu köye Bâlî Beyoğlu Kasım Bey tarafindan 921 (1515) yılında türbe yaptırılmıştır..$^{90}$ Bir süre sonra cami ve diğer binalar inşa edilerek, buras1 külliye haline dönüştürülmüştür.91 Şeyh Şücâüddin'in faaliyetlerini sürdürdüğü bu tekke ve türbesinin bulunduğu köy uzun yıllar onun adıyla anılmıştır. Eskişehir'in Seyitgazi ilçesine $6 \mathrm{~km}$. mesafede bulunan bu köyün adı 1968 yılında Arslanbeyli olarak değiştirilmiştir. Seyitgazi'deki türbenin dışında kendisine Edirne ve Antalya'da iki makam türbesi daha nisbet edildiği rivayet edilmektedir. $^{92}$

\section{Otman Baba}

Osmanlı Devleti'nin tanınmış Kalenderî dervişlerinden biri de Otman Babadır. Gerçek adı Hüsamşah olan Otman Baba'nın hayatı hakkındaki bilgiler, halifelerinden Küçük Abdal'ın yazmış olduğu Velâyetnâme-i Otman Baba adlı esere dayanmaktadır. Menâkıbnâmede ifade edildiğine göre Otman Baba 780 (1378-79) yılında doğmuştur. Hayatının büyük bir kısmını Rumeli'de geçirmiş, özellikle bugünkü Bulgaristan coğrafyasında derin izler bırakmış, heterodoks bir Türk dervişi olarak tanımlanmaktadır. Rivayete göre gençliğinde, Timur'un Anadolu'yu istilâsı sırasında bölgeye gelmiş, ${ }^{93}$ Sultan II. Murat döneminde; Bursa, İznik, Germiyan, Saruhan ve havâlisinde uzun müddet dolaşmıştır. Ayrıca II. Mehmed'in şehzadeliğindeki Manisa valiliği sırasında burada bulunmuştur ${ }^{94}$. Küçük Abdal onun halk arasında Otman Baba diye bilindiğini, erenlerin ise ona Hüsam Şah dediklerini rivayet etmiştir. ${ }^{95}$ Otman Baba'nın Oğuz dili konuştuğunu, cüssesinin heybetli, sırtı yassı, yüzü kızıl, gözleri ela ve nazarının himmetli olduğunu, sırrına kimsenin vâkıf olamayacağını ifade etmiştir. ${ }^{96}$

${ }^{90}$ Filiz Aydın, "Seyitgazi Arslanbeyli Köyü’nde Şeyh Şücaaddin Külliyesi”, Vakıflar Dergisi, C.9, Tipkı Basım, PYS Vakıf Sistem Matbaası, Ankara, 2006, s.208.

${ }^{91}$ Külliye hakkında ayrıntılı bilgi için bakınız: Aydın, a.g.m.,s.201-221; Erol Altınsapan, "Seyitgazi İlçesi Arslanbeyli Köyü Seyh Sücaaddin Külliyesi", Türk Kültürü ve Hacı Bektaş Velî Araşstrrma Dergisi, Şücaaddin Veli Ocă̆ 1 Özel Sayıs1, S.37, Bahar 2006, s.173-184.

${ }^{92}$ Sahin, "S̈ücâüddin Velî", s.248.

${ }^{93}$ Filiz Kılıç, Mustafa Arslan, Tuncay Bülbül, Otman Baba Velayetnamesi (Tenkitli Metin), Ankara, 2007, s.17;Yunus Yalçın, Türk Edebiyatında Velâyetnâmeler ve Otman Baba Velâyetnâmesi, Erciyes Üniversitesi Sosyal Bilimler Enstitüsü, Yayınlanmamış Yüksek Lisans Tezi, Kayseri, 2008, s.62;Kemal Üçüncü, "Sözlü Kültür Bağlamında Edebi Bir Metin Olarak Otman Baba Vilayetnamesi”, Bilig, Kış 2004, S.28, s.16.

${ }_{94}$ Ocak, Osmanlı Împaratorluğu’nda Marjinal Sûfilik, s.99; Yalçın, a.g.t., s.63.

${ }^{95}$ Halil İnalcık, "Otman Baba ve Fatih Sultan Mehmed", Osmanlılar Fütühat, İmparatorluk, Avrupa ile İlişkiler, Timaş Yayınları, İstanbul, 2010, s.138.

${ }^{96}$ Haşim Şahin, "Otman Baba", DİA, C.XXXIV, İstanbul, 2007, s.6-7; Yalçın, a.g.t., s.61 
Otman Baba, beraberindeki yüzlerce derviș ile birlikte İstanbul'a gelmiş, Göztepe ve Terkos yakınlarında bir süre ikamet ettikten sonra Balkanlar'a geçmiştir. Burada muhtelif yerlere ziyaretlerde bulunmuş, halka yardım etmiş ve abdalları için kurban toplamıştır. Aydos, Babaeski, Dobruca, Zağra, Filibe, Tırnova, Edirne, Vize, Siroz, Belgrad, Semendire, Ağaç denizi, Balkan dağı gibi mekanlar gezdiği yerler arasında zikredilmektedir. Yaz aylarında Ahmed Baba (Vize), Mü'min Derviş (Zağra), Bayezid Baba (Vardar), Mecnun Derviş (Serez) ve Nasuh Baba (Karasu Yenicesi) gibi dönemin meşhur Kalenderî zâviyelerini dolaşmış, kışları Varna ve Edirne'deki zâviyesinde geçirmiştir. ${ }^{97}$ Gittiği yerlerde, kazınmış saç, sakal, kaş ve bıyıkları, belden yukarısı hayvan postuyla örtülmeye çalışılmış çıplak vücutları, boyunlarında keşkülleri, ellerinde asaları ile dikkat çekmişlerdir. Onların bu durumunu görenler, deli zannetmişler ve şikâyette bulunmuşlardır. Bu sebeple sık sık halk ve yöneticiler ile kavgalar meydana gelmiş, şehir ve kasabalardan içeri sokulmak istenmemiştir. ${ }^{98}$

Balkanlar'da Yörükler ve özellikle Tanrıdağı Yörükleri arasında faaliyet gösterdiği rivayet edilen Otman Baba'nın, Rumeli'de birçok şeyh, derviş, baba ve abdal ile münasebet kurduğu belirtilmiştir. Halil İnalcık eserinde onun abdallarının çoğunun Doğu Balkan dağları veya Dobruca Yörüklerinden teşekkül etmiş fakir çobanlardan oluştuğunu söylemiştir. ${ }^{99}$ Abdallarıyla birlikte Balkanlar'daki fetih hareketlerine katılıp, gazilerle birlikte savaşan Otman Baba onlarla yakın dostluk kurmuş, devlet adamlarının yardımlarını kesinlikle kabul etmemiştir. Otman Baba'nın yakınlık kurduğu akıncı gazilerin başında Mihaloğlu Ali Bey de gelmektedir. Velâyetnâme'de Ali Bey'in Otman Baba'ya karşı çok saygıll davranışlarda bulunduğundan bahsedilmektedir. ${ }^{100}$

Osmanlı Devleti'nde Otman Baba'nın yakın ilişkide bulunduğu kişilerden biri de Fâtih Sultan Mehmed'dir. Rivayete göre Otman Baba, Fâtih'in şehzadeliği döneminde, Sultan'ın rüyasına girerek kendini tanıtmış ve Rum diyarına onu padişah yapmak için geldiğini söylemiştir. Velâyetnâme'deki bilgilerden anlaşılacağı üzere, Otman Baba'nın, Fâtih'i sultan olarak tanıdığı ve kendisinin evreni yöneten kutup olduğu ve izni olmaksızın hiçbir şeyin gerçekleşmeyeceği vurgulanmaya çalışılmıştır. ${ }^{101}$ Esere göre Fâtih Sultan Mehmet, Belgrad seferine çıkmayı düşündüğünde Otman Baba sefere çıkmamasını tavsiye etmiş, çıktığı takdirde başarısız olacağını söylemiştir. Fâtih, bu söz üzerine çok sinirlenmiş ve kılıcını çıkararak Otman Baba'ya saldırmak istemiştir. Ancak bu sırada yanında bulunan Mahmud Paşa Sultan'1 sakinleștirerek, Otman Baba'nın velayet sahibi olduğunu söylemiştir. Belgrad seferinin başarısızlıkla sonuçlanması üzerine Fâtih, Otman Baba'nın üstünlüğünü tanımak zorunda kalmış ve onun velayet gücüne tam bir inanç göstermiştir. Ayrıca yaşanan bu olaydan sonra dervişe karşı son derece hürmetkâr, lütufkâr ve itaatkâr davranmaya başlamıştır. ${ }^{102}$ Eserde, başta Mahmud Paşa olmak üzere Fâtih'in yanındaki devlet adamlarının da Otman Baba'nın "sırr-1 velâyet" olduğunu bildikleri vurgulanmaktadır. ${ }^{103}$ Yaşanan bu olaydan sonra Otman Baba, bir gün şehirde dolaşırken Fâtih Sultan Mehmet ile karşıllaşmıştır. Fâtih Sultan Mehmet'e şu soruyu sormuş: çabuk söyle, "sultan sen misin yoksa ben miyim?" Fatih Sultan Mehmet ise; "padişah sensin ve sırr1 Hüdâ'sın, ben ise senin kemine kemter kulunum babacı̆̆ım" diye cevap vermiştir. ${ }^{104}$

${ }^{97}$ Ocak, Osmanlı Imparatorluğu’nda Marjinal Sufilik, s.98; Şahin, “Otman Baba", s.7.

${ }^{98}$ Ocak, Osmanlı Imparatorluğu'nda Marjinal Sûfílik, s.100.

99 İnalc1k, a.g.e., s.146.

100 Gökhan Yurtoğlu, “Otman Baba'nın Tarikatına Dair”, Türk Kültürü ve Hacı Bektaş Velî Araştırma Dergisi, Kış 2016 / Sayı 80, s.143-144.

${ }^{101}$ İnalc1k, a.g.e., s.138-140; Üçüncü, a.g.m., s.16-17.

${ }^{102}$ Yalçın, a.g.e., s.84.

${ }^{103}$ İnalcık, a.g.e., s.152-153; Şahin, “Otman Baba”, s.7; Üçüncü, a.g.m., s.17.

${ }^{104}$ Yalçın, a.g.e., s.87.

${ }^{105}$ İnalc1k, a.g.e., s. 153.

${ }^{106}$ Ziya Avşar, "Otman Baba Vilâyet-nâmesi'ne Göre Otman Baba ile Rumeli

Bölgesindeki Babaların Münâsebetleri”, 2.Uuluslarası Türk Kültür Evreninde
Otman Baba, gayr-i sünnî görüşleri sebebiyle medrese mühitleri tarafindan Fâtih Sultan Mehmed'e şikâyet edilmiştir. ${ }^{105}$ Bu şikâyetler neticesinde mahkemede sorgulanmıştır. Fakat o, ölünceye kadar fikirlerini savunmaya devam etmiştir. Otman Baba, medrese mensuplarının yanı sıra o dönemindeki bazı tarikat şeyhleriyle de anlaşamamıştır. Bu gruplar ile anlaşamamasında, onların dünya malı biriktirmek, şan ve şöhret peşinde koşmak, iktidara yakın çevrelerle iş birliği yapmak, halka yalan yanlış mârifet satmak, kurdukları vakıfları evlâdiyelik hale dönüştürmek gibi bir takım suçlamaların büyük payı bulunmaktadır. Otman Baba'nın Bektaşî ileri gelenleriyle ilişskilerinin de pek iyi olmadığı görülmektedir. Küçük Abdal, onun Şücâüddin Baba, Arık Çoban (Koyun Baba) ${ }^{106}$ ve Hacı Bektâş-1 Velî dışında geçmişte ve kendi döneminde yaşayan hiçbir velîyi kabul etmediğini, abdallarına çok düşkün olduğunu, bütün istek ve hevesleri terk edip hak aşkı ile dolan ve âlemdeki her şeyi Hak'tan bilenleri gerçek abdal kabul ettiğini söylemektedir. Otman Baba'nın köprü yaptırdığı, abdallarından $1 \mathrm{SSs}$ alanlara çeşmeler kurup sular akıtmalarını istediği ve Balkanlar'ı yerleşim yeri haline getirmeye çalıştığ ${ }_{1}$ kaydedilmektedir. ${ }^{107}$

Eserde Otman Baba'nın pek çok mucizevi kerametinden de bahsedilmektedir. Azerbaycan taraflarından İstanbul'a bir buluta binip geldiği, yıldırımı kendisine kamçı yaptığı, tabiata hükmetme gücüne sahip olduğu, firtına çıkarıp yağmur yağdırdığı gibi muhtelif efsanevi kerametleri anlatılmaktadır. Otman Baba'nın ölüm tarihine dair, mezar taşındaki bilgi ile velâyetnâmede yer alan ifadeyi karşılaştırdığımız zaman, onun hicrî 883 milâdî 1478/1479 yılında hayatını kaybettiği tahmin edilmektedir. Otman Baba vefat ettiğinde ulema ve abdallardan oluşan yaklaşık iki bin kişi cenaze namazı için toplandığı rivayet edilmektedir. ${ }^{108}$ Mezarı Varna'daki zâviyesinde bulunmakta olup, bugün mevcut türbe binas1, 1506 yılında yapılmıştır. ${ }^{109}$

\section{Koyun Baba}

Osmancık'ta yaşadığı bilinen Koyun Baba hakkındaki malumatlar, XVI. yüzyılda yazıya geçirilmiş olan Velâyetnâme-i Koyun Baba adlı esere dayanmaktadır. ${ }^{110}$ Koyun Baba, Horasan'da doğmuş ve sekizinci imam olan İmam Ali Rıza'nın soyundan gelmektedir. ${ }^{111}$ Eserde Seyyid Ali adıyla zikredilen Koyun Baba, Horasan'da vaktinin çoğunu ibadetle ve halkın dertlerine çare aramakla geçirirken bir gece rüyasında $\mathrm{Hz}$. Peygamber'i görmüş ve onun emriyle hacca gitmiştir. Akabinde Medine ve Kerbelâ'yı ziyaret ettikten sonra irşad vazifesiyle Anadolu'ya gönderilmiştir. ${ }^{112}$

Koyun Baba'nın ismine dair kaynaklarda farklı rivayetler bulunmaktadır. Evliya Çelebi, Seyehatname adlı eserinde Horasan'dan Anadolu'ya gelirken yaptığı yolculuk esnasında her yirmi dört saatte bir koyun gibi melediği için kendisine Koyun Baba lakabının verildiğini söylemiştir. ${ }^{113}$ Yumuşak huya sahip bir insan olduğu ya da bir gün sürüden kaçan bir koyunu kovalarken bir tepeyi yedi defa dolaşıp, koyunu yakaladığında, "Yâ mübarek, kendin yoruldun, beni de Hz. Eyyûb sabrına nâil ettin" dediği için bu adla
Alevîlik ve Bektâşîlik Bilgi Şöleni Bildiri Kitabı, C.1, Ankara, 2007, s.406-407; Yalçın, a.g.t., s.68.

${ }^{107}$ Şahin, "Otman Baba", s.7-8.

${ }^{108}$ Kılıç vd, a.g.e., 270.

${ }^{109}$ Ocak, Osmanlı Imparatorluğu'nda Marjinal Sûfilik, s.100; Şahin, “Otman Baba", s.8.

110 Muzaffer Doğanbaş, Koyun Baba Velâyetnamesi, Dört Kapı Yayınevi, İstanbul, 2015, s.30.

111 M. Şakir Çıplak, Osmancık'ta Erenler Durağl Koyun Baba, Horasan Yayınları, İstanbul, 2001, s.24-25.

112 Ahmet Taşğın, Horasandan Balkanlara Ulaşan Eren Koyun Baba ve Menakıbı, Çizgi Kitabevi, Konya, 2017, s.67.

${ }^{113}$ Evliya Çelebi, Seyehatname 2. Cild 1. Kitap, s.211. 
anıldığına dair rivayetler de mevcuttur. ${ }^{114}$ Horasan'da başladığ yolculuğunun sonunda Bursa'ya gelen Koyun Baba, burada koyun çobanlığ 1 yapmaya başlamıştır. ${ }^{115}$ Bursa'ya geldiği andan itibaren gösterdiği kerametler sayesinde nüfuz sahibi olmuştur. ${ }^{116}$ Halk arasında bazı Kalenderî dervişler çok fazla eleştirilmiştir. Fakat Koyun Baba fukaraları, yumuşak huylu, kötülüklerden kaçan kişiler oldukları için pek fazla eleştiriye maruz kalmamışlardır. Bu kişiler Hakk'1 bilir, ehl-i sünnet ve'l-cemaat namaz k1lan insanlar olarak tarif edilmektedir. ${ }^{117}$

Koyun Baba, Osmanlı Devleti'nin ünlü hükümdarlarından biri olan Fâtih Sultan Mehmed tarafından itibar görmüș, önemli dervişlerden biridir. Nitekim bu durum velâyetnâmelerde de ayrıntılı bir şekilde ele alınmıştır. Pîri Baba Velâyetnâmesi'nde; Fâtih Sultan Mehmed Merzifon'dan İstanbul'a giderken Osmancık şehrine uğramış ve Koyun Baba'nın yanına giderek “merhaba etmek murad eylemiş”tir, fakat Koyun Baba, Sultan'a bu görüşme öncesinde Beylerbeyine uğrayıp uğramadığını sormuştur. Padişah bu soruya "Sultan'ım beylerbeyi kimdir?" sorusuyla karşılık vermiştir. Koyun Baba "Merzifon'da eski hamam külhanında sakin olan Piri Baba'dır" demiş, padişah da Koyun Baba'ya: "Hay Dede Sultan biz dediğin kimsenin himmetiyle gideriz" cevabını vermiştir. ${ }^{118}$

Fâtih Sultan Mehmed'in, Piri Baba'yı yücelten cevabı üzerine Koyun Baba, sultanla görüşmüştür. Fâtih, bu görüşmede Koyun Baba'nın kendisinden ne istediğini sormuştur. Koyun Baba da sultandan müridlerin yaşamını sürdürmesi için bir köy, abdallara aba ve yüz elli altın istediğinde bulunmuştur. Hükümdar, Koyun Baba'nın bu isteklerini kabul etmiş ve gereken işlemlerin yapılması için harekete geçmiştir. Koyun Baba'nın hükümdardan istekleri Piri Baba'ya malûm olmuş ve o bu olay üzerine, eleştirel bir üslupla: "Koyun Baba gayri dünya meşakkatine düşdi” diye söylenmiştir. ${ }^{119}$

Koyun Baba, Fâtih Sultan Mehmed ile buluştuğu zaman yanında bulunan on yedi dervişine helal haram konusunda öğütlerde bulunarak bu hususta kaygı ve endişe taşıdığını açıkça göstermiştir. Koyun Baba "vakıf etmeğini benim kazanıma koymayın dibini deler; hak teâlâ dergâhında bulgur bulamaç el verir"120 diyerek harama ve helale karşı hassasiyetini göstererek, dervişlerin dünya nimetlerine alışmasından çekindiğini açıkça ortaya koymuştur. Ayrıca Koyun Baba, dervişlerine ayende ve ravendeyi(gelen ve gideni) hoş tutmalarını ve ellerinde olanı Allah rızası için harcamaların öğütlemiştir. ${ }^{121}$ Koyun Baba'nın bu tavsiyesi diğer dervişlerde olduğu gibi dünya malına fazla tamah edilmemesi gerektiği ve bir lokma bir hırka felsefesini benimsediğini gösterir.

Fâtih Sultan Mehmed, Uzun Hasan üzerine sefere çıktığı zaman, Osmancık'a uğrayarak Koyun Baba'yı ziyaret etmiştir. Velâyetnâme'de uzun bir şekilde anlatılan bu ziyaret sırasında Koyun Baba Fâtih'i "Allah erlerinin şahı" diye vasıflandırıp, Uzun Hasan'a karș1 galip olacağı müjdesini vermiștir. ${ }^{122}$ Fâtih de Koyun Baba'yı zamanın kutbu olarak gördüğüne dair konuşmasının akabinde kendisine etraftaki köyleri vakfetme ve büyük bir tekke yaptırma sözü vermiștir. Ancak Koyun Baba Fâtih'in bu lütfunu kabul etmeyip,

114 Zeki Gürel, Koyun Baba, Yörtürk Yörük Türkmen Vakfı Yayınları, Ankara, 2000, s.166-167; Hacı Yılmaz, "Bilinmeyen Bir Koyunbaba Menâkıbnâmesi Üzerine”, Hacı Bektaş Veli Araștırma Dergisi, Ankara, 1999 s.24.

${ }^{115}$ Taşğın, Horasandan Balkanlara, s.68; Çıplak, Osmancık'ta Erenler Dură̆ Koyun Baba, s.28-29.

116 Çıplak, Osmancık'ta Erenler Durağı Koyun Baba, s.57-58;Taşğın, Horasandan Balkanlara, s.68; Gürel, a.g.e., s.166-167.

${ }^{117}$ Evliya Celebi, Seyehatname 2. Cild 1. Kitap, s.211.

${ }^{118}$ Doğanbaş, Koyun Baba Velâyetnamesi, s.21-22; Çıplak, Osmancık'ta Erenler Durağı Koyun Baba, s.93.

${ }^{119}$ Doğanbaş, Koyun Baba Velâyetnamesi, s.21-22;Taşğın, Horasandan Balkanlara, s.159; Ciplak, Osmancık'ta Erenler Durağ Koyun Baba, s.93-94.

${ }^{120}$ Doğanbaş, Koyun Baba Velâyetnamesi, s.49; Çıplak, Osmancık'ta Erenler Durağ̆ Koyun Baba, s.95; Zekeriya Işık, "Osmanlı İmparatorluğu'nda Devlet Tarikat İlișkileri Bağlamında Koyun Baba”, Uluslararası Nehrin Piri. Koyunbaba Sempozyumu, 13 - 14 Mayıs, Çorum, 2016, s.14.
Kızılırmak üzerine bir köprü yaptırmasını istemiştir. ${ }^{123}$ Ayrıca Koyun Baba Padişahtan kışın ve yazın yaşamlarını sürdürdükleri yaylalardan vergi alınmaması talebinde bulunmuştur. Sultan onun isteklerinin hepsini kabul ederek, adı geçen yerlerin vergiden muaf tutulmasına dair ferman yayımlamıştır. Fâtih Sultan Mehmed köprünün yapılması için niyetlenmiştir. Ancak ömrü bu köprünün yapımına yetmediği için oğlu II. Bayezid zamanında köprü inşa edilmiştir. ${ }^{124}$

Yaşamının geri kalan kısmını müridlerini yetiștirerek geçirdiği rivayet edilen Koyun Baba, türbesinin kitabesindeki bilgilere göre 25 Muharrem 873'te (15 Ağustos 1468) vefat etmiştir. Rivayete göre öleceğini müridlerine önceden haber vermiş ve türbesinin kârgir taştan yapılmasını dair isteğini Mahmud Dede adlı müridine vasiyette bulunmuştur. ${ }^{125} \mathrm{II}$. Bayezid tarafindan yaptırıldığı rivayet edilen bu türbe Kızılırmak yakınında Arafat tepe üzerinde bulunmakta olup, üstü kurşun kubbeyle örtülüdür. ${ }^{126}$ Koyun Baba'nın İstanbul'da Fatih ve Galata, Ankara-Kalecik, Edirne, Denizli, Konya ve YugoslavyaKalkandelen'de olmak üzere toplam yedi makam türbesinin daha bulunduğu rivayet edilmektedir. Günümüzde de Koyun Baba'nın türbelerine halkın ilgi ve alakası yoğun bir şekilde devam etmektedir. 127

\section{Sonuç}

Osmanlı Devleti'nin kuruluş sürecinde, Anadolu'da varlığını sürdüren tasavvufi zümreler toplumsal ve siyasal yönden önemli bir yer teșkil etmişlerdir. $\mathrm{Bu}$ gruplar Anadolu'da Türkleșme ve İslamlaşma faaliyetlerine büyük katkıda bulunmuşlardır. Anadolu Selçuklu Devleti'nin dağılma sürecine girmesiyle birlikte bulundukları bölgede nüfuzlarını arttırmışlardır. Osmanlı devleti de kuruluş sürecinde maddi ve manevi olarak bu gruplardan faydalanmış, bölgede siyasi ve iktisadi birliği bu suretle sağlamıştır.

Osmanlı Devleti'nin ilk dönemlerinde Osmanlı sultanları yaşadıkları dönemin şartlarına göre Kalenderîler ile dostane ilişkiler içerisinde olmuş ve onlara birçok imtiyaz tanımışlardır. Kuruluş döneminde, Kalenderî gruplarda Osmanlı sultanlarını yalnız bırakmamış ve yapılan fetihlerde ön saflarda yer almışlardır. Nitekim Kalenderî dervişlerden Abdal Murad, Doğlu Baba ve Postinpûş Baba'nın Osmanlı sultanlarının maiyetinde fetih hareketlerine iştirak ettikleri ve savaş esnasında keramet gösterdikleri de tarihi kaynaklarda ifade edilmiştir. Osmanlı padişahları bu hizmetlerine karşıllk onlara tekke ve zâviye açmıştır. Ayrıca bazı bölgelerde onları vergiden muaf tutmuştur. Kuruluş devrinin ilk dönemlerinde Kalenderî gruplar daha çok Anadolu coğrafyasında sınır boylarında ve taşralarda yaşamlarını sürdürmüșlerdir.

Devletin teşkilatlanması ve fetihlerin artmasına bağlı olarak Yıldırım Bayezid ve sonraki dönemlerde ise Rumeli ve Balkanlarda Kalenderî zümreye mensup kişiler yer almaya başlamıştır. Seyyid Ali Sultan (Kızıl Deli), Şûcâeddin Veli, Otman Baba ve Koyun Baba Rumeli ve Balkanlarda aktif olan dervişlerdendir. Bu dervişlerde tıpkı Anadolu'daki gibi birçok fetih hareketine katılmış, Rumeli ve Balkanların İslamlaşması ve Türkleșmesinde büyük rol

\footnotetext{
${ }^{121}$ Doğanbaş, Koyun Baba Velâyetnamesi, s.49; Yağmur Say, "Hacı Bektaş Tipolojisinin Şücâ'eddîn Velî Ve Koyun Baba Simgesel Kimliklerindeki İzleri”, Hacı Bektaş Velî’nin Tarihsel Kimliği, Düșünce Sistemi Ve Etkileri, III. Uluslararası Türk Kültürü Ve Hacı Bektaş Velî Sempozyumu, 30-31 Ekim 2009, Scopje (Üsküp), Ankara, 2010, s.161; Taşğın, Horasandan Balkanlara, s.225-226.

${ }^{122}$ Taşğın, Horasandan Balkanlara, s.150.

${ }^{123}$ Gürel, a.g.e., s.58-59; Ocak, Osmanlı Împaratorluğu'nda Marjinal Sûfîlik, s.95; Çıplak, Osmancık'ta Erenler Durağı Koyun Baba, s.93; Taşğın, Horasandan Balkanlara, s.151.

${ }^{124}$ Çılak, Osmancık'ta Erenler Dură̆ Koyun Baba, s.94-95; Semavi Eyice, “Beyazıt II Köprüsü”, DİA, C.VI, İstanbul, 1992, s.51.

${ }^{125}$ Taşğın, Horasandan Balkanlara, s.71-72.

${ }^{126}$ Evliya Celebi, Seyehatname 2. Cild 1. Kitap, s.211.

${ }^{127}$ Haşim Şahin, "Koyun Baba", DİA, C.XXVI, Ankara, 2002, s.230
} 
oynamışlardır. Balkanlar'a gelerek İslamiyet'i yaymaya çalışan bu dervişler İslam dininin alt yapısını oluşturmuşlardır. Nitekim Balkanlar'a yerleșmiş olan bu dervişler yaşam tarzları ile Osmanlı Devleti'nin bölgeyi feth etmesini ve Balkanlarda ve Rumeli'de kalıcılığını kolaylaştırmıştır. Heterodoks inanca sahip bu dervişler Osmanlının azamet dönemine doğru gittiği süreçte devletin din politikası çerçevesinde ya bu toprakları terk etmişler yada marjinal yapılarını kaybederek devletin kontrolündeki tasavvufi zümreler içerisinde erimişlerdir. 


\section{KAYNAKÇA}

Ahmed Eflâkî, Âriflerin Menkıbeleri, Çev: Tahsin Yazıcı, C.II, Hürriyet Yayınları, İstanbul, 1973.

Akkuş, Mustafa, İlhanlıların Anadolu'daki Dini Siyaseti, Selçuk Üniversitesi Sosyal Bilimler Enstitüsü, Yayınlanmamış Doktora Tezi, Konya, 2011.

Akkuş, Mustafa, “Anadolu Selçuklu Devletinin Yıkılmasında Kalenderi Grupların Rolü”,Turkish Studies, Volume 9/7, Ankara, 2014.

Akkuş, Mustafa, Bağc1, Büşra, "Hülâgû Han Döneminde Anadolu'da Görev Yapan Moğol Komutanları”, USAD, Güz 2018, S.9, ss.150-171.

Akkuş, Mustafa, Moğollarda Din ve Siyaset İlhanlı Hanlarının Dini Kişiliği ve Uygulamaları, Çizgi Kitabevi, Konya, 2020.

Altınsapan, Erol, "Seyitgazi İlçesi Arslanbeyli Köyü Şeyh Şücaaddin Külliyesi”, Türk Kültürü ve Hacı Bektaş Velî Araştırma Dergisi, Şücaaddin Veli Ocağı Özel Sayısı, S.37, Bahar 2006, ss.173-184.

Âş1kpaşaoğlu Ahmed Âşıkî, Tevârîh-i Âl-i Osman, Düzenleyen: Nihal Atsız, Türkiye Yayınevi, İstanbul, 1947.

Âşık Paşazâde, Osmanoğulları’nın Tarihi, Haz., Kemal Yavuz, M.A. Yekta Saraç, K Kitaplığı, İstanbul, 2003.

Avşar, Ziya, “Otman Baba Vilâyet-nâmesi’ne Göre Otman Baba ile Rumeli Bölgesindeki Babaların Münâsebetleri”, 2.Uuluslarası Türk Kültür Evreninde Alevîlik ve Bektâş̂llik Bilgi Şöleni Bildiri Kitabı, C.1, Ankara, 2007, ss.405-412.

Aydın, Filiz, “Seyitgazi Arslanbeyli Köyü’nde Şeyh Şücaaddin Külliyesi”, Vakıflar Dergisi, C.9, Tıpkı Basım, PYS Vakıf Sistem Matbaası, Ankara, 2006, ss.201-221.

Azamat, Nihat, "Kalenderiyye”, DİA, C.XXIV, İstanbul, 2001.

Barkan, Ömer Lütfi, “Osmanlı İmparatorluğunda Bir İskân ve Kolonizasyon Metodu Olarak Vakıflar ve Temlikler I:İstila Devirlerinin Kolonizatör Türk Dervişleri ve Zaviyeler," Vakıflar Dergisi, 1942, S.2, s.279-300.

Bilgili, Ali Sinan, "Osmanlı Arşiv Belgelerine Göre Kızıldeli (Seyyid Ali Sultan) Zâviyesi (1401 - 1826)”, Türk Kültürü ve Hacı Bektaş Veli Araştırma Dergisi, S.53, Ankara, 2010, ss.89-114.

Çıplak, M. Şakir, Osmancık'ta Erenler Durağı Koyun Baba, Horasan Yayınları, İstanbul, 2001.

Doğanbaş, Muzaffer, Koyun Baba Velâyetnamesi, Dört Kapı Yayınevi, İstanbul, 2015.

Döğüş, Selahattin, Osmanlı Devleti'nin Doğuşunda Sosyal Kuruluşlar, Erciyes Ün. Sos. Bilimler Ens. Kayseri, 1999.

Evliya Çelebi, Günümüz Türkçesi ile Evliya Çelebi Seyehatnamesi: Bursa, Bolu, Trabzon, Erzurum, Azerbaycan, Kafkasya, Kırım, Girit, Hazırlayanlar: Yücel Dağl1, Seyyid Ali Kahraman, 2. Cilt, 1. Kitap, 2. Baskı, Yap1 Kredi Yayınları, İstanbul, 2008.

Eyice, Semavi, “Beyazıt II Köprüsü”, DİA, C.VI, İstanbul, 1992.

Gelibolulu Mustafa Âli Efendi, Kitâbü't- Târih-i Künhü'l-Ahbâr, Hazırlayanlar: Ahmet Uğur, Ahmet Gül, Mustafa Çuhadar, İbrahim Hakk1 Çuhadar, Erciyes Üniversitesi Yayınları, C.I, İkinci Kısım, Kayseri, 1997.

Gülten, Sadullah, “Tahrir Defterlerine Göre Anadolu'da Kalenderîler ve Haydarîler”, Tarih Araştırmaları Dergisi, C. XXXI, S.52, 2012, s.3553.

Gürel, Zeki, Koyun Baba, Yörtürk Yörük Türkmen Vakfı Yayınları, Ankara, 2000.

Hoca Sadettin, Tacü't-Tevarih, Yalınlaştıran: İsmet Parmaksızoğlu, C.1, Kültür Bakanlığı Yayınları, Ankara, 1979.

Hoca Sadettin, Tacü't-Tevarih, Sad.: İsmet Parmaksızoğlu, C.5, Kültür Bakanlığı Yayınları, Ankara, 1992.

Hüseyin Hüsameddin Efendi, Amasya Tarihi, haz: Mesut Aydın-G. Aydın, C.II, Amasya Belediyesi Kültür Yayınları, Amasya, 2008.

Işık, Zekeriya, “Osmanlı İmparatorluğu'nda Devlet Tarikat İlişkileri Bağlamında Koyun Baba”, Uluslararası Nehrin Piri: Koyunbaba Sетроzуити, 13 - 14 Mayıs, Çorum, 2016, s.1-18.

İbn Kemal, Tevârih-i Âli Osman, II. Defter, Yayına Hazırlayan: Şerafettin Turan, TTK, 2. Baskı, Ankara, 1991.

İnalcık, Halil, “Otman Baba ve Fatih Sultan Mehmed”, Osmanlılar Fütühat, İmparatorluk, Avrupa ile İlişkiler, Timaş Yayınları, İstanbul, 2010.

Karamustafa, Ahmet T., Tanrının Kuraltanımaz Kulları, Çev. Ruşen Sezer, Yapı Kredi Yayınları, İstanbul, 2008.

Kâşânî, Cemalü'd-din Ebu'l Kasım Abdullah b. Muhammed b. Ebi Tahir, Tarih-i Olcâytû, Tercüme: Derya Örs, Ankara Üniversitesi Sosyal Bilimler Enstitüsü, Yayınlanmamış Y. Lisans Tezi, Ankara, 1992.

Kayapınar, Ayşe, “Trakya-Doğu Rodop Bölgesinde Alevi-Bektaşi Zaviyeleri (XV-XVI. Yüzyılllar)”, Alevilik-Bektaşilik Araştırmaları Dergisi, S.18, 2018, ss.3-38.

K1lıç, Filiz, Arslan, Mustafa, Bülbül, Tuncay, Otman Baba Velayetnamesi (Tenkitli Metin), Ankara, 2007. 
Köprülü, Orhan F., "Velâyet-nâme-i Sultan Şücaüddin”, Türkiyat Mecmuası, C.XVII, İstanbul, 1972, ss.177-184.

Köprülü, Orhan F., “Abdal Murad”, DİA, C.I, İstanbul, 1988.

Köprülü, Fuat, Türk Tarih-i Dinîsi, Haz: Metin Ergun, Akçağ Yayınları, Ankara, 2005.

Mecdî Mehmet Efendi, Şakaik-i Nu'maniye ve Zeyilleri (Hadâiku'ş-Şekâik),C.I, nş. Haz. Abdülkadir Özcan, Çağrı Yayınları, İstanbul, 1989.

Mehmed Neşrî, Kitâb-ı Cihan-nümâ Neşrî Tarihi, Hazırlayanlar: Faik Reşit Unat, Mehmed Altay Köymen, C.I, Türk Tarih Kurumu Basımevi, Ankara, 1949.

Müneccimbaşı Ahmed B. Lütfullah, Camiü'd-Düvel (Osmanlı Tarihi 1299-1481), Çeviri: Ahmet Ağırakça, İnsan Yayınları, İstanbul, 1995. Ocak, Ahmet Yaşar, Osmanlı İmparatorluğunda Marjinal Sufilik Kalenderîler (XIV-XVII. yüzyıllar), TTK Yayınları, Ankara, 1992.

Ocak, Ahmet Yaşar, "Barak Baba”, DİA, C.V, İstanbul, 1992.

Ocak, Ahmet Yaşar, Osmanlı Toplumunda Zındıklar ve Mülhidler (15-17 Yüzyıllar), Tarih Vakfı Yurt Yayınları, İstanbul, 2013.

OruçBeğ, Oruç Beğ Tarihi, Baskıya Hazırlayan: Atsız, Kervan Kitapçılık, İstanbul, 1972.

Say, Yağmur, “Anadolu’nun Türkleşmesi ve İslamlaşmasında Önemli Bir Kült Kimlik: Şücaaddin Veli (Sultan Varlı̆̆ı)”, Türk Kültürü ve Hacı Bektaş Velî Araştırma Dergisi, Şücaaddin Veli Ocağı Özel Sayısı, S.37, Bahar 2006, s.99-133.

Say, Yağmur, “Hacı Bektaş Tipolojisinin Şücâ'eddîn Velî ve Koyun Baba Simgesel Kimliklerindeki İzleri”, Hacı Bektaş Velî’nin Tarihsel Kimliği, Düşünce Sistemi ve Etkileri, III. Uluslararası Türk Kültürü Ve Hacı Bektaş Velî Sempozyumu, 30-31 Ekim 2009, Scopje (Üsküp), Ankara, 2010

Say, Yağmur, Kalenderî, Alevi ve Bektaşi Kültünde Önemli Bir Alp-Eren Gazi: Şucâ'eddîn Velî (Sultan Varlığı) ve Velâyetnâmesi, Sistem Ofset Matbaacılık, 1. Basım, Ankara, 2010.

Seyyid Ali Sultan (Kızıldeli Sultan) Velayetnamesi, Haz: Bedri Noyan, Ayyıldız Yayınları, Ankara, 1999.

Seyyid Ali Sultan (Kızıldeli) ve Velâyetnâmesi, Haz: Rıza Yıldırım, Türk Tarih Kurumu Yayınları, Ankara, 2007.

Şahin, Haşim, “Koyun Baba”, DİA, C.XXVI, Ankara, 2002.

Şahin, Haşim, Osmanlı Devleti'nin Kuruluş Döneminde Dinî Zümreler (1299-1402), Yayınlanmamış Doktora Tezi, Marmara Üniversitesi Türkiyat Araştırmaları Enstitüsü, İstanbul, 2007.

Şahin, Haşim, “Otman Baba”, DİA, C.XXXIV, İstanbul, 2007.

Şahin, Haşim, “Seyyid Ali Sultan”, DİA, C.XXXVII, İstanbul, 2009.

Şahin, Haşim, "Şücâüddin Velî", DİA, C.XXXIX, İstanbul, 2010.

Şahin, Haşim, Dervişler, Fakihler, Gaziler, Erken Osmanlı Döneminde Dinî Zümreler (1300-1400), 2. Baskı, Yapı Kredi Yayınları, İstanbul, 2020.

Şemseddin Sami, Kâmûs-ı Türk̂̂, T.C. Kültür Bakanlığı Yayıncılık, 1.Baskı, İstanbul, 2016.

Taşğın, Ahmet, Horasandan Balkanlara Ulaşan Eren Koyun Baba ve Menakıbı, Çizgi Kitabevi, Konya, 2017.

Taşköprülüzâde, Osmanlı Bilginleri eş-Şakâiku'n-Nu'mâniyye fî ulemâi'd-Devleti'l-Osmâniyye, Çeviren: Muharrem Tan, İz yayıncılık, İstanbul, 2007.

Turğut, Vedat, “XVI. Yüzyılda Tahrir Defterlerine Göre Hüdavendigar ve Sultanönü Sancaklarında Abdalân-1 Rum”, Uluslararası Sosyal Araştırmalar Dergisi, C.4 S.19, Güz 2011, ss.207-227.

Uyar, Mustafa, “Bir Ortaçağ Anadolu Sûfìsi Hakkında Yeni Bulgular: Aybek Baba Şeyh mi, Emîr mi?”, Belleten, C.LXXVIII, S.283, (December 2014).

Üçüncü, Kemal, "Sözlü Kültür Bağlamında Edebi Bir Metin Olarak Otman Baba Vilayetnamesi”, Bilig, Kış 2004, S.28, ss.1-27.

Ülken, Hilmi Ziya, Anadolu’nun Dinî Sosyal Tarihi (Öncüler Barak Baba, Geyikli Baba, Hacı Bektaş), Çeviren ve Yayına Hazırlayan: Ahmet Taşğın, Kalan Yayınları.

Yalçın, Yunus, Türk Edebiyatında Velâyetnâmeler ve Otman Baba Velâyetnâmesi, Erciyes Üniversitesi Sosyal Bilimler Enstitüsü, Yayınlanmamış Yüksek Lisans Tezi, Kayseri, 2008.

Yazıcı, Tahsin, "Cemâleddin-i Sâvî”, DIA, C.VII, İstanbul, 1993.

Yıldırım, Rıza, "Bektaşî-Alevî Geleneğine Göre Seyyid Ali Sultan”, Türk Kültürü ve Hacı Bektaş Veli Araştırma Dergisi, S.53, Ankara, 2010, ss.59-88.

Yurtoğlu, Gökhan, “Otman Baba'nın Tarikatına Dair”, Türk Kültürü ve Hacı Bektaş Velî Araştırma Dergisi, Kış 2016 / Sayı 80, ss.137-150. 
Yıldız, Ayşe, “Şücaaddin Baba Velâyetnamesi”, Türk Kültürü ve Hacı Bektaş Velî Araştırma Dergisi, Şücaaddin Veli Ocağı Özel Sayısı, S.37, Bahar 2006, ss.49-98.

Yılmaz, Hacı, "Bilinmeyen Bir Koyunbaba Menâkıbnâmesi Üzerine”, Hacı Bektaş Veli Araştırma Dergisi, Ankara, 1999. 